\title{
Mammalian Target of Rapamycin Signaling Is a Key Regulator of the Transit-Amplifying Progenitor Pool in the Adult and Aging Forebrain
}

\author{
Grigorios N. Paliouras, ${ }^{1}$ Laura K. Hamilton, ${ }^{1}$ Anne Aumont, ${ }^{1}$ Sandra E. Joppé, ${ }^{1}$ Fanie Barnabé-Heider, ${ }^{2}$ \\ and Karl J. L. Fernandes ${ }^{1}$ \\ ${ }^{1}$ Department of Pathology and Cell Biology, Groupe de recherche sur le système nerveux central and Center of Excellence in Neuroscience of the Université de \\ Montréal, Université de Montréal, Montréal, Quebec, Canada, H3T 1J4, and ²Department of Neuroscience, Karolinska Institutet, S-17177 Stockholm, Sweden
}

Adult forebrain neurogenesis is dynamically regulated. Multiple families of niche-derived cues have been implicated in this regulation, but the precise roles of key intracellular signaling pathways remain vaguely defined. Here, we show that mammalian target of rapamycin (mTOR) signaling is pivotal in determining proliferation versus quiescence in the adult forebrain neural stem cell (NSC) niche. Within this niche, mTOR complex-1 (mTORC1) activation displays stage specificity, occurring in transiently amplifying (TA) progenitor cells but not in GFAP + stem cells. Inhibiting mTORC1 depletes the TA progenitor pool in vivo and suppresses epidermal growth factor (EGF)induced proliferation within neurosphere cultures. Interestingly, mTORC1 inhibition induces a quiescence-like phenotype that is reversible. Likewise, mTORC1 activity and progenitor proliferation decline within the quiescent NSC niche of the aging brain, while EGF administration reactivates the quiescent niche in an mTORC1-dependent manner. These findings establish fundamental links between mTOR signaling, proliferation, and aging-associated quiescence in the adult forebrain NSC niche.

\section{Introduction}

Adult neural stem cells (NSCs) balance between two seemingly contradictory biological states. While most of their time is spent in a state of quiescence, a mechanism for preserving genomic stability and extending cellular lifespan, they must simultaneously generate sufficient numbers of differentiated progeny to preserve tissue integrity, function, and regenerative capacity ( $\mathrm{Li}$ and Clevers, 2010; Nakada et al., 2011). In the forebrain, NSCs reconcile these disparate functions by maintaining a large pool of highly proliferative transiently amplifying (TA) progenitors within the subventricular zone (SVZ) of the lateral ventricles (Morshead et al., 1994; Chojnacki et al., 2009; Ihrie and AlvarezBuylla, 2011). TA progenitors undergo rapid proliferative expansion, producing differentiating neuroblasts that migrate to the olfactory bulbs and that are recruited to other brain regions following injury, such as stroke (Arvidsson et al., 2002; Kolb et al., 2007; Thored et al., 2007). Maintenance of the TA progenitor pool is essential for dynamic modulation of cell genesis in response to physiological or pathophysiological changes. However,

\footnotetext{
Received May 5, 2012; revised Aug. 2, 2012; accepted Aug. 28, 2012.

Author contributions: G.N.P., F.B.-H., and K.J.L.F. designed research; G.N.P., L.K.H., A.A., S.E.J., and F.B.-H. performed research; G.N.P., L.K.H., F.B.-H., and K.J.L.F. analyzed data; G.N.P. and K.J.L.F. wrote the paper.

This work was supported by a fellowship from the Groupe de recherche sur le système nerveux central (G.N.P.) and a Canada Research Chair in Stem Cell Neurobiology (K.J.L.F.). Operating funds were provided by the Canadian Institutes of Health Research. We thank members of the Fernandes laboratory for helpful discussions and technical assistance.

The authors declare no competing financial interests.

Correspondence should be addressed to Dr. Karl J. L. Fernandes, Département de pathologie et biologie cellulaire, Université de Montréal, C.P. 6128, succursale Centre-ville, Montréal, QC, Canada H3C 3J7. E-mail: karl.jl.fernandes@umontreal.ca.

DOI:10.1523/JNEUROSCI.2248-12.2012

Copyright $\odot 2012$ the authors $\quad 0270-6474 / 12 / 3215012-15 \$ 15.00 / 0$
}

the majority of TA progenitors disappear with aging (Maslov et al., 2004; Luo et al., 2006; Molofsky et al., 2006; Bouab et al., 2011), including in humans (Knoth et al., 2010), potentially contributing to aging-associated deficits in neural functions and brain maintenance. Thus, understanding how TA progenitors expand from a small number of stem cells has widespread therapeutic relevance.

Expansion of the TA progenitor pool is regulated by many families of extracellular "extrinsic" factors within the NSC niche (Tropepe et al., 1997; Palma et al., 2005; Colak et al., 2008; Aguirre et al., 2010; Ihrie and Alvarez-Buylla, 2011). In particular, epidermal growth factor (EGF)-related ligands play particularly prominent roles. The EGF receptor (EGF-R) is expressed by TA progenitors and a subpopulation of stem cells (Doetsch et al., 2002; Pastrana et al., 2009), and EGF is routinely used in culture to isolate and expand tripotential neural progenitors from the adult brain (Reynolds and Weiss, 1992; Doetsch et al., 2002). Mice deficient in transforming growth factor $\alpha$, another EGF-R ligand, have significantly reduced SVZ neurogenesis (Tropepe et al., 1997), emphasizing the importance of EGF-R signaling for adult neurogenesis. However, less is known about the exact functions of intracellular signaling pathways activated downstream of niche-derived signals. These signaling pathways represent potential therapeutic targets for modulating adult neurogenesis during aging, disease, and injury.

Here, we define novel biological functions of the mammalian target of rapamycin (mTOR) pathway within the adult and aging NSC niche. mTOR is a highly conserved, serine-threonine kinase that regulates numerous essential cellular processes, including transcription, translation, ribosome biogenesis, autophagy, cyto- 
skeletal dynamics, and cell survival (Zoncu et al., 2011). In various cell types, mTOR signaling can be modulated downstream of multiple growth factor receptors and sensors of nutrients, energy, and stress (Zoncu et al., 2011). Moreover, upstream mutations that hyperactivate mTOR signaling in embryonic neural precursors result in tuberous sclerosis complex-associated CNS lesions (Magri et al., 2011). We now demonstrate that mTOR signaling in the adult forebrain NSC niche is critical for TA progenitor expansion and aging-associated quiescence.

\section{Materials and Methods}

Tissue collection. All experiments were conducted in accordance with the guidelines of the Canadian Council of Animal Care and were approved by the University of Montreal animal care committee. Pregnant C57BL/6 mice (Charles River), 2-, 10-, and 18-month-old male C57BL/6 mice (Taconic), and GFAP-GFP mice (stock \#003257, The Jackson Laboratory) were used in these experiments. Freshly dissected embryonic tissues and formaldehyde perfusion-fixed adult tissues were postfixed overnight in $4 \%$ formaldehyde. Adult tissues were cut into $40 \mu \mathrm{m}$ coronal sections using a vibratome (Leica VT1000S) and stored at $-20^{\circ} \mathrm{C}$ in antifreeze solution (Bouab et al., 2011), while embryonic tissues were cryoprotected in $30 \%$ sucrose, cryostat sectioned at $15 \mu \mathrm{m}$ thickness and stored at $-80^{\circ} \mathrm{C}$.

Microdissected SVZ and striatal samples were obtained from freshly dissected adult mouse brains as follows. Brains were placed in a brain mold and straight-edge razor blades were used to cut a 2-mm-thick coronal section through the forebrain (corresponding to the region between 3 and $5 \mathrm{~mm}$ posterior to the anterior edge of the olfactory bulbs). Using a dissecting microscope, fine-tipped tungsten needles were then used to dissect out a block of SVZ tissue, by first making lateral cuts through the corpus callosum (dorsally) and above the anterior commissures (ventrally), and then tracing the gray-white boundaries at the SVZ/ striatum and SVZ/septum borders. A block of striatal tissue of similar size was cut from the center of the adjacent striatum for biochemical comparison and to provide a control for SVZ microdissection purity.

Neurosphere cultures and neural differentiation. Neurosphere cultures were generated at clonal density in DMEM/F-12 (3:1; both from Invitrogen) supplemented with 2\% B27 (Invitrogen), $1 \mu \mathrm{g} / \mathrm{ml}$ fungizone (Invitrogen), $1 \%$ penicillin/streptomycin (Wisent), $20 \mathrm{ng} / \mathrm{ml} \mathrm{EGF} \mathrm{(Sigma),}$ and $25 \mathrm{ng} / \mathrm{ml}$ fibroblast growth factor-2 (FGF2; Sigma) as described previously (Bouab et al., 2011). Primary neurospheres were grown for $7 \mathrm{~d}$ before quantification of number and diameter. The self-renewal properties of primary neurospheres were assessed by passaging the primary cultures in the above proliferation medium at a cell density of $0.5 \mathrm{cells} / \mu \mathrm{l}$ to ensure the growth of clonally derived secondary spheres (ColesTakabe et al., 2008). DMSO, rapamycin (Invitrogen), or KU0063794 (chemical formula $\mathrm{C} 25 \mathrm{H} 31 \mathrm{~N} 5 \mathrm{O} 4$; Tocris Bioscience) were used at the concentrations indicated and were replenished every $2 \mathrm{~d}$. The number and diameter of secondary neurospheres was quantified after $7 \mathrm{~d}$ in vitro.

To assess the effects of acute stimulation with EGF on mTOR signaling, neurosphere cells plated in proliferation medium were deprived of EGF, FGF2, and the insulin-containing B27 supplement for one night and were then stimulated with $100 \mathrm{ng} / \mathrm{ml}$ of EGF for 0, 15, and $30 \mathrm{~min}$. Cells were analyzed by Western blotting (see below).

Primary neurospheres were differentiated as described previously (Bouab et al., 2011). After the indicated times, cells were either lysed for analysis by Western blotting or fixed in $4 \%$ formaldehyde for $15 \mathrm{~min}$ for immunocytochemistry. To assess the effects of mTOR inhibition on differentiation of neurospheres, DMSO, rapamycin (20 nM), or KU0063794 $(100 \mathrm{~nm})$ were added to the differentiation medium and replenished every $2 \mathrm{~d}$.

Immunostaining. Immunohistochemistry and immunofluorescence were performed on tissue sections and cultured cells as detailed previously (Bouab et al., 2011). Working dilutions and sources of antibodies used in this study were as follows: mouse anti-rat $\beta$ III tubulin (1:500; Covance); mouse anti-human CNPase (1:500), guinea pig anti-mouse doublecortin (DCX; 1:1000), and rabbit anti-mouse Olig2 (1:500; Millipore), rabbit anti-cow $S 100 \beta$ (1:1000; Sigma); rabbit anti-cow glial fibril- lary acidic protein (GFAP; 1:1000; Dako Diagnostics); chicken anti-GFP (1:500; Aves); mouse anti-human Ki67 (1:200), mouse anti-rat mammalian achaete scute homolog 1 (Mash1; 1:100), and mouse anti-rat Nestin (1:400; BD Biosciences); and rabbit anti-human phospho-S6 ribosomal protein (P-S6-RP; Ser240/Ser244; 1:300) and rabbit anti-mouse phospho-4EBP1 (Thr37/46; 1:500; Cell Signaling Technology). For fluorescence detection, secondary antibodies were diluted in PBS and incubated with sections/cells for $45 \mathrm{~min}$ at room temperature, and nuclei were counterstained with Hoechst $33342(0.2 \mu \mathrm{M}$, Sigma-Aldrich) for 2 $\mathrm{min}$. For peroxidase-based detection using 3,3-diaminobenzine, sections were incubated in the appropriate biotinylated secondary antibody for 90 min at room temperature and the signal revealed using the avidin-biotin-peroxidase system (VectaStain ABC Kit, Vector Laboratories) according to the manufacturer's instructions. Secondary antibodies used included CY3 goat anti-mouse (1:400), CY3 goat anti-rabbit (1:400), biotin goat anti-mouse IgG $(\mathrm{H}+\mathrm{L} ; 1: 1000)$, biotin goat anti-rabbit IgG (H+L; 1:1000; Jackson ImmunoResearch), goat anti-rabbit Alexa 488/ 647, goat anti-mouse Alexa 488, donkey anti-rabbit Alexa 488, goat antiguinea pig Alexa 555, and goat anti-mouse IgG Alexa 555 (all diluted to 1:1000; Invitrogen).

Western blotting. Protein samples were prepared and separated by Western blotting as described previously (Bouab et al., 2011). Fifty micrograms of protein from each sample were run per lane. Working dilutions and sources of antibodies used in this study included rabbit anti-human phospho-Akt (Ser473; D9E) XP (1:1000), rabbit antihuman Akt (1:1000), rabbit anti-human cleaved caspase-3 (Asp175; 1:500), rabbit anti-human phospho-mTOR (Ser2448; 1:1000), rabbit anti-mouse mTOR (1:1000), rabbit anti-human phospho-S6ribosomal protein (Ser240/Ser244; 1:1000), mouse anti-human S6 ribosomal protein (1:1000), rabbit anti-mouse phospho-4EBP1 (Thr37/46; 236B4; 1:500), rabbit anti-mouse 4EBP1 (1:1000), rabbit anti-human P-Rictor (Thr1135; D30A3; 1:500), and rabbit anti-human Rictor (53A2; 1:500; Cell Signaling Technology); rabbit anti-mouse calretinin (1:5000; Swant); mouse anti-human CNPase (1:1000), rabbit anti-human Sox2 (1: 500), rabbit anti-human tyrosine hydroxylase (1:1000; Millipore); rabbit anti-cow GFAP (1:5000; Dako Diagnostics); mouse anti-human proliferating cell nuclear antigen (PCNA; 1:1000; BD Biosciences); and mouse anti-rat $\beta$ III tubulin (1:1000; Covance). Horseradish peroxidase-conjugated antimouse IgG (1:5000; Bio-Rad) or anti-rabbit IgG (1:5000; Millipore) secondary antibodies were used. Secondary antibodies were detected using the enhanced chemiluminescence reagent kit following manufacturer's instruction (GE Healthcare) and X-Omat Blue film (Kodak). Membranes were subsequently stripped with Re-Blot Plus Mild (Millipore), reblocked, and reprobed appropriately. Densitometric quantifications were performed using NIH ImageJ 64-bit Java Software for Mac.

Transfection and DNA constructs. The transfection reagent Lipofectamine 2000 (Invitrogen) was used according to the manufacturer's instructions for HEK293 cells. For neurosphere experiments, primary neurospheres were gently triturated and $1 \times 10^{5}$ cells were plated into 8 -well chamber slides coated with poly-L-lysine. A concentration of 0.5 $\mu \mathrm{g}$ of wild-type (WT) mTOR (Addgene plasmid 1861) or kinase-dead (KD) mTOR (Addgene plasmid 8482) were cotransfected with $0.5 \mu \mathrm{g}$ of red fluorescence protein-expressing vector. Cells were incubated in the DNA/Lipofectamine mix for $4 \mathrm{~h}$, and the medium then changed to proliferation medium for $2 \mathrm{~d}$. Following $2 \mathrm{~d}$ of proliferation, cells were induced to differentiate by EGF withdrawal.

Intracerebroventricular infusions. Mice were operated under isofluorane anesthesia. Stereotaxic coordinates for implantation of Alzet brain infusion cannulae (Brain infusion kit 3, $3 \mathrm{~mm}$ depth; Durect) were 0.0 $\mathrm{mm}$ anteroposterior and $0.9 \mathrm{~mm}$ lateral relative to Bregma. Cannulae were attached to $7 \mathrm{~d}$ Alzet osmotic pumps (model 1007D; Durect), which delivered $0.5 \mu \mathrm{l} / \mathrm{h}$. Growth factor or inhibitor solutions were prepared in $1 \%$ albumin at the following concentrations: EGF, $20 \mu \mathrm{g} / \mathrm{ml}$; rapamycin, $0.5 \mathrm{~mm}$. DMSO was used as the vehicle control.

Microscopy. Fluorescence and light microscopy were performed using a motorized Olympus IX81 epifluorescence microscope equipped with a black and white CCD camera and an Olympus BX43F light microscope equipped with a DP21 color digital camera. Confocal microscopy was performed using a Leica SP1 laser-scanning system or an Olympus IX61 
spinning disc laser system. Image manipulations were limited to brightness/ contrast and were performed in a standardized manner for all images.

Quantifications and statistical analyses. For anti-P-S6-RP doublelabeling experiments, two to three sections (four to six ventricles per animal) between the stereotaxic coordinates of bregma 0.0 and $+1.2 \mathrm{~mm}$ were analyzed from each of three animals, and the percentage of P-S6$\mathrm{RP}+$ cells that were double labeled is reported.

For quantification of Ki67+ and Mash1+ cells in 2-month-old and 10-month-old mice following intracerebroventricular (ICV) infusion of DMSO, rapamycin, EGF or EGF plus rapamycin, quantifications were limited to the side ipsilateral to pump implantation, as P-S6-RP staining showed that the effects of rapamycin were restricted to the side of infusion. Two to three sections between bregma 0.0 and $+1.2 \mathrm{~mm}$ (i.e., the region of efficient P-S6-RP inhibition) were used from each of three animals to obtain a total of $18-24$ fields of view ( $40 \times$ magnification). Nuclear size measurements showed no significant differences in diameter across treatment groups ( 2 months, DMSO, $7.60 \pm 0.13 \mu \mathrm{m} ; 2$ months, rapamycin, $7.98 \pm 0.19 \mu \mathrm{m} ; 10$ months, DMSO, $7.55 \pm 0.41$ $\mu \mathrm{m} ; 10$ months, EGF, $7.41 \pm 0.14 \mu \mathrm{m} ; 10$ months, EGF plus rapamycin, $7.88 \pm 0.14 \mu \mathrm{m})$. Quantifications from $40-\mu \mathrm{m}$-thick sections are therefore presented as uncorrected cell counts per mm of SVZ length, providing an estimation of relative changes in cell numbers in each group.

Two-tailed unpaired $t$ tests were used to compare the means between pairs of groups and statistical significance was set at $p \leq 0.05$. Error bars depict the SEM. All statistical analyses were performed using GraphPad Prism for Windows (version 5.02).

\section{Results \\ mTOR signaling is activated within zones of developing and adult neurogenesis}

The biological functions of mTOR are mediated by two known mTOR-containing signaling complexes, mTORC1 and mTORC2, whose activation can be monitored by phosphorylation of distinct downstream substrates, including S6-RP, 4EBP1, and Rictor (for mTORC1) or Akt (for mTORC2) (Sarbassov et al., 2005; Zoncu et al., 2011; Laplante and Sabatini, 2012). Phosphorylated S6-RP (P$\left.\mathrm{S} 6-\mathrm{RP}^{\mathrm{Ser240/244}}\right)$, in particular, is a sensitive and highly specific indicator of mTOR signaling.

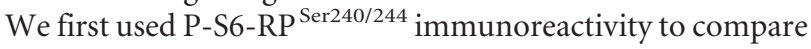
the distribution of mTOR activation in the developing and the adult CNS. At embryonic day 15 (E15), P-S6-RP immunoreactivity was abundant throughout the neural tube, including in the germinal ventricular zones and the expanding parenchyma of both the brain and spinal cord (Fig. 1A-D). P-S6-RP+ cells in the ventricular zone of the E15 telencephalon represented a subpopulation of the Nestin + neural stem/progenitors (Fig. 1A,B). Similarly, in the caudal neural tube, P-S6-RP+ cells were a subpopulation of the Vimentin + cells within the ventricular zone of the developing spinal cord (Fig. 1C,D).

$\mathrm{P}-\mathrm{S} 6-\mathrm{RP}^{\mathrm{Ser} 240 / 244}$ cells were likewise distributed widely throughout the parenchyma of the adult brain and spinal cord; however, in contrast to the embryonic CNS, P-S6-RP+ cells were largely absent from adult ventricular zones (Fig. $1 E-H$ ). The exception to this was the SVZ bordering the striatal wall of the lateral ventricles, notable for its ongoing adult neurogenesis, where P-S6-RP+ cells represented a subpopulation of the Nestin + cells (Fig. 1E,F). P-S6-RP+ cells were virtually absent from the medial and dorsal walls of the lateral ventricles (Fig. 1E), where neurogenesis is less common. Likewise, P-S6-RP + cells were absent from the Vimentin + ependymal layer of the spinal cord, which is also nonneurogenic (Fig. 1G,H). $\mathrm{P}-\mathrm{S} 6-\mathrm{RP}+$ cells within the parenchyma of the adult brain and spinal cord corresponded to mature neurons, while GFAP+ astrocytes were notably negative (data not shown).

Biochemical analyses confirmed the activation of mTORinduced signaling pathways in the adult forebrain SVZ niche (Fig.
$1 I-K)$. Lysates were generated from microdissections of the lateral ventricle SVZ and from the adjacent striatal tissue (Fig. 1I). The purity of these microdissections was confirmed by Western blotting for region-specific markers, including tyrosine hydroxylase (striatum specific) and Sox2, PCNA, and calretinin (SVZ enriched) (Fig. 1J). Compared to the adjacent striatum, SVZ lysates were found to be enriched for phosphorylated mTOR itself $\left(\mathrm{P}-\mathrm{mTOR}^{\mathrm{Ser} 2448}\right)$, for downstream substrates of mTORC1 (P-S6$\mathrm{RP}^{\text {Ser240/244 }}, \mathrm{P}-4 \mathrm{EBP} 1^{\text {Thr37/46 }}$, and P-Rictor $\left.{ }^{\text {Thr1135 }}\right)$, and for the mTORC2-dependent Ser473 phosphorylation site of Akt (P$\mathrm{Akt}^{\mathrm{S} 473}$ ) (Sarbassov et al., 2005) (Fig. 1J). Quantification by densitometry indicated that the relative phosphorylation levels of mTOR, S6-RP, and Akt were all two to four times higher in the SVZ than in the adjacent striatum (Fig. $1 \mathrm{~K}$ ); moreover, since these SVZ microdissections included the medial and dorsal walls of the ventricles, this is likely an underestimation of the enrichment of mTOR activity within the neurogenic lateral SVZ.

Thus, mTOR-associated signaling pathways are widely activated in ventricular zones during developmental neurogenesis and are selectively maintained within the adult forebrain SVZ neurogenic niche.

\section{mTORC1 activation occurs in TA progenitors and is required} to maintain the endogenous TA progenitor pool

The four principal cell types within the SVZ niche of the adult mouse forebrain are ependymal cells, astrocytes (including the astrocyte-like stem cells), TA progenitors, and neuroblasts, whose lineage relationships and markers have been well characterized (Fig. 2A) (Doetsch et al., 1997, 1999). Since only a fraction

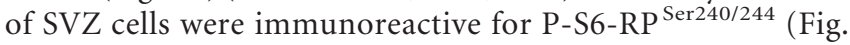
$2 B$ ), we performed multilabel immunofluorescence for P-S6$\mathrm{RP}^{\mathrm{Ser} 240 / 244}$ and cell type-specific markers (Fig. 2C-H). Quantification revealed that $94.7 \pm 2.0 \%$ of $\mathrm{P}-\mathrm{S} 6-\mathrm{RP}+$ cells were immunoreactive for the proliferation marker Ki67, 81.1 $\pm 3.7 \%$ expressed Mash1 (neuronally specified TA progenitors), $7.6 \pm$ $4.3 \%$ expressed Olig2 (TA progenitors and oligodendrocytelineage cells), and $15 \pm 6.9 \%$ expressed the neuroblast marker DCX (Fig. 2C-I ). P-S6-RP ${ }^{\text {Ser240/244 }}$ cells represented $16.1 \pm 2.7 \%$ of the total Ki67+ cells and $25.1 \pm 6.0 \%$ of the total Mash $1+$ cells (Fig. $2 \mathrm{~J}$ ). Immunostaining for a second mTORC1 target, P-4EBP $1^{\text {Thr37/46 }}$, showed a qualitatively similar labeling pattern, with the majority of P-4EBP1 + cells coexpressing Mash 1 (Fig. $2 K$ ).

Notably, P-S6-RP staining was absent in both GFAP + astrocytes/stem cells (Fig. 2D) and S100 $\beta+$ ependymal cells (Fig. 2C), suggesting that $\mathrm{mTORC} 1$ activation in vivo does not occur in cells having stem cell potential. In particular, the GFAP + stem cell compartment is thought to be comprised of both quiescent $($ GFAP + Ki67 - ) and rarer "activated" (GFAP+Ki67+) subpopulations. We therefore exhaustively analyzed $>600$ P-S6$\mathrm{RP}+$ cells in $z$-stacks through the SVZ using a $60 \times$ objective (data not shown) and never detected P-S6-RP immunoreactivity in GFAP + cells. Furthermore, immunostaining of sections from the SVZ of GFAP-GFP transgenic mice likewise revealed no colocalization between P-S6-RP and GFP (Fig. $2 L$ ). Together, these data indicate that activation of mTORC1 signaling does not occur to any significant extent in GFAP + NSCs, and that mTORC1 signaling within the adult SVZ neurogenic lineage first occurs within the TA progenitor compartment.

To gain insight into the potential role(s) of mTOR signaling within the TA progenitor population, we next used osmotic pumps to infuse $0.5 \mu \mathrm{l} / \mathrm{hr}$ of $500 \mu \mathrm{M}$ rapamycin continuously into the lateral ventricles for $7 \mathrm{~d}$. Rapamycin is a widely tested, clinically approved, 

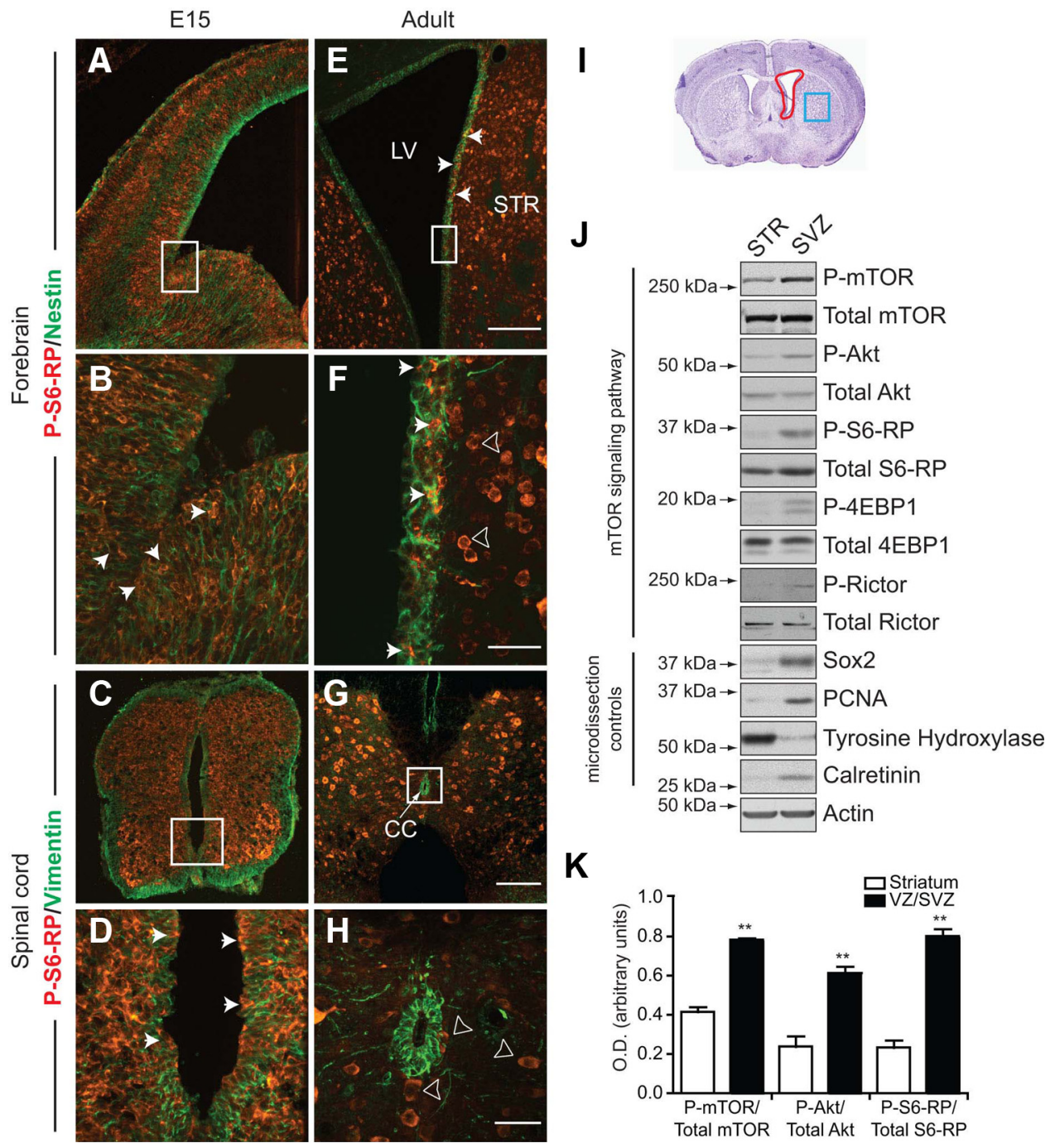

Figure 1. Activation of mTOR signaling pathways in neurogenic zones of the developing and adult CNS. A-D, Confocal images of immunofluorescence for P-S6-RP (red) within the Nestin-expressing (green) ventricular zone of the E15 telencephalon ( $\boldsymbol{A}$, enlarged in $\boldsymbol{B}$ ) and within the Vimentin-expressing (green) ventricular zone of theE15 spinal cord ( $\boldsymbol{C}$, enlarged in $\boldsymbol{D})$. Cells simmunoreactive for P-S6-RP are widespread in the ventricular zones and expanding parenchyma throughout the E15 CNS. E-H, Confocal images of immunofluorescence for P-S6-RP (red) and Nestin (green) in the SVZ of the 2-month-old adult forebrain lateral ventricles (LV; $\boldsymbol{E}$, enlarged in $\boldsymbol{F}$ ), and for P-S6-RP (red) and Vimentin (green) surrounding the 2-month-old spinal cord central canal (G, enlarged in $\boldsymbol{H}$ ). CC, Central canal. Cells immunoreactive for P-S6-RP remain detectable within the neurogenic striatal SVZ (arrows; $\boldsymbol{E}, \boldsymbol{F}$ ), but are no longer present within the ependymal layer of the spinal cord. Arrowheads in $\boldsymbol{F}$ and $\boldsymbol{H}$ point out strong P-S6-RP immunoreactivity in mature neurons throughout the CNS. I-K, Biochemical detection of mTOR signaling activity in the adult forebrain striatal SVZ.I, Schematic showing the SVZ (red box) and striatum (STR, blue box) regions that were microdissected from $2 \mathrm{~mm}$ sections of the adult mouse forebrain.J, Representative Western blots of SVZand STR lysates probed with a variety of microdissection controls (Sox2, PCNA, tyrosine hydroxylase, and calretinin) and for components of mTOR signaling pathways ( $m$ TOR, Akt, S6-RP, 4EBP1, and Rictor). Levels of P-mTOR, P-Akt, P-S6-RP, P-4-EBP1, and P-Rictor are all elevated within the SVZ relative to the adjacent striatum. $\boldsymbol{K}$, Average densitometry ratios for P-mTOR/mTOR, P-S6-RP/S6-RP, and P-Akt/Akt ( $n=6$ separate experiments). ${ }^{* *} p<0.01$. Scale bars: (in $\boldsymbol{E}$ ) $\boldsymbol{A}, \boldsymbol{E}, 200 \mu \mathrm{m}$; (in $\left.\boldsymbol{F}\right) \boldsymbol{B}, \boldsymbol{F}, 40 \mu \mathrm{m}$; (in $\boldsymbol{G}$ ) $\boldsymbol{C}, \boldsymbol{G}$, $400 \mu \mathrm{m}$; (in $\boldsymbol{H}) \boldsymbol{D}, \boldsymbol{H}, 40 \mu \mathrm{m}$.

and highly specific allosteric inhibitor that operates by binding FKBP12 to inhibit mTORC1 activation. Immunostaining confirmed that ICV infusion of rapamycin was effective in abolishing P-S6-RP ${ }^{\text {Ser240/244 }}$ within a 1-2 $\mathrm{mm}$ span of the ipsilateral SVZ and surrounding striatal tissue (Fig. 3A,D). Immunostaining for Ki67 on adjacent tissue sections revealed that in vivo administration of rapamycin reduced the pool of constitutively proliferating SVZ cells to $48.47 \pm 3.5 \%$ of that found in DMSO-infused animals (Fig. $3 B, E, G)$. This was primarily due to a reduction in TA progenitors, as the number of Mash1+ cells likewise decreased to $64.70 \pm 1.7 \%$ compared to DMSO infusion (Fig. 3C, F, H). Furthermore, this decrease was attributable to reduced proliferation rather than increased apoptosis, as immunostaining for cleaved caspase-3 showed that regardless of treatment, apoptotic cells could be seen surrounding the cortical cannula tract but were only rarely detectable within the SVZ (Fig. 3I). No obvious effects on astrocyte-associated GFAP immunoreactivity were observed (data not shown), consistent with the lack of astrocyte-associated mTORC1 activity described previously (Fig. 2). DCX + neuroblasts were still present following rapamycin infusion, but changes in their number could not be reliably assessed owing to significant changes in neuroblast migration patterns toward the cortical pump implantation site (data not shown).

Together, these results indicate that endogenous mTOR signaling is important for maintaining the size of the proliferating TA progenitor pool in vivo.

\section{mTOR activity mediates EGF-induced expansion of adult neurosphere cultures}

The above findings suggested that mTOR signaling mediates the proliferative effects of endogenous niche-derived signals. Since 
A
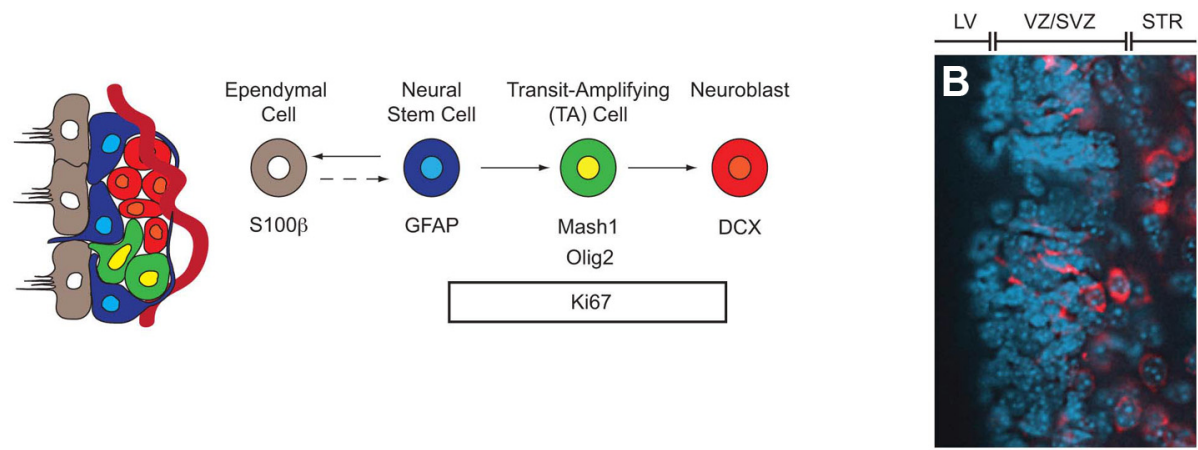

Hoechst/P-S6-RP



\begin{tabular}{lll}
\cline { 2 - 4 } Mash1 & Dcx & Olig2
\end{tabular}

I
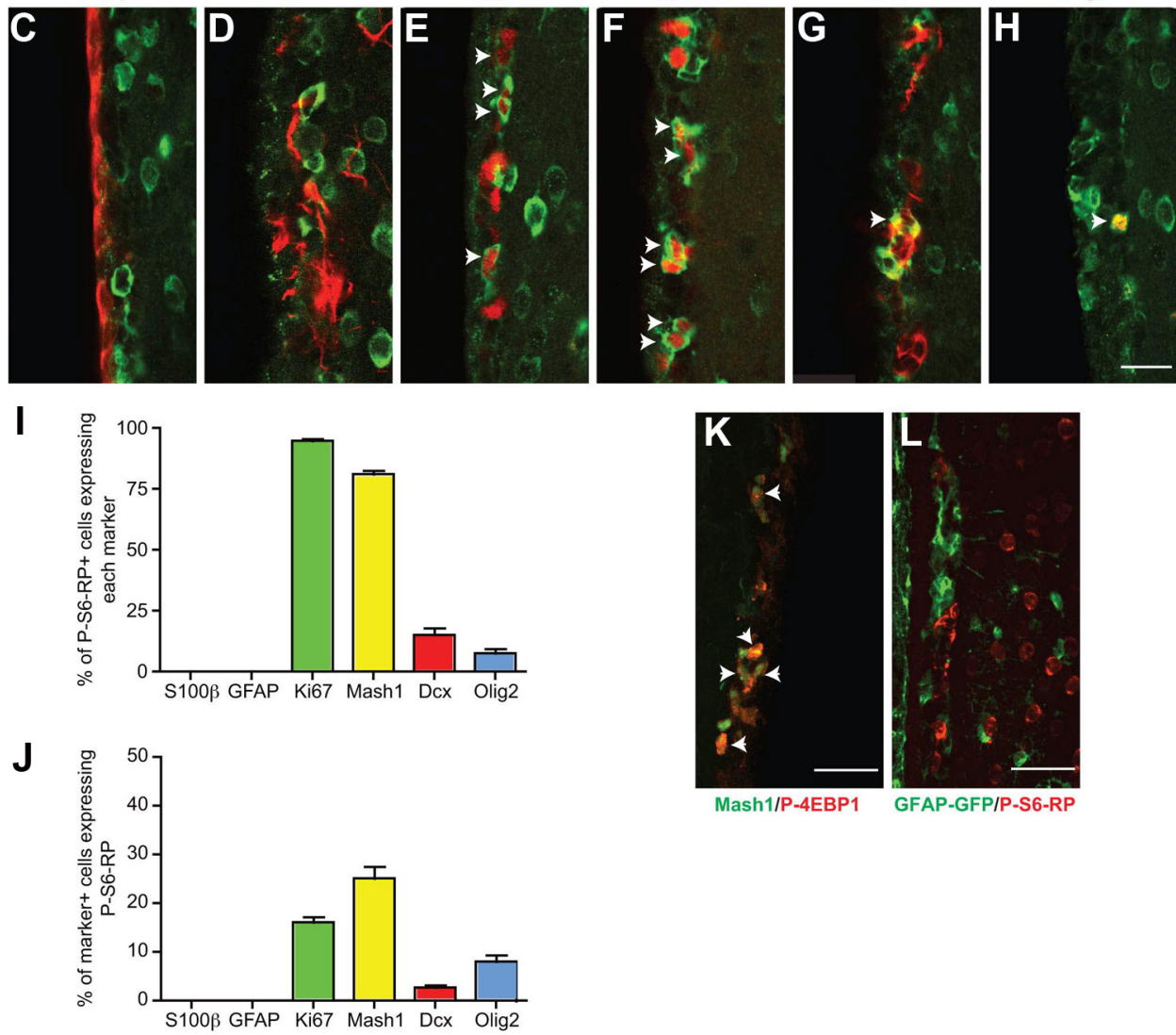

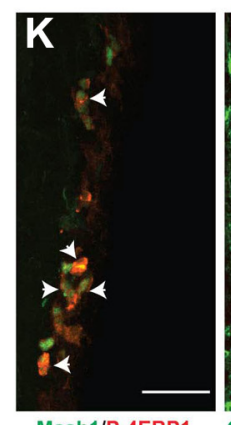

Mash1/P-4EBP1

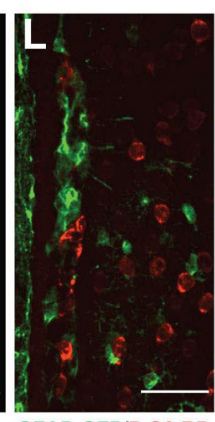

GFAP-GFP/P-S6-RP

Figure 2. mTOR signaling occurs in TA progenitor cells but not GFAP + cells within the adult forebrain SVZ niche. $A$, lllustration of the principal cell types in the SVZ neurogenic lineage and their associated cell type-specific markers. $\boldsymbol{B}$, Immunostaining for P-S6-RP (red) reveals expression in only a discrete subset of SVZ cells. Nuclei are counterstained with Hoechst. $\mathbf{C}-\boldsymbol{H}$, Multilabel immunofluorescence for P-S6-RP (green) and cell type-specific markers (red). The vast majority of P-S6-RP-positive cells are proliferating TA progenitors as defined by expression of Ki67 (E), Mash1 $(\boldsymbol{F})$ and/or Olig2 $(\boldsymbol{H}) . \boldsymbol{I}, \boldsymbol{J}$, Quantification of immunofluorescence experiments, expressed as a percentage of P-S6-RP cells $(\boldsymbol{I})$ or as a percentage of marker-positive cells $(\boldsymbol{J}) . \boldsymbol{K}$, Immunofluorescence staining for Mash1 (green) and P-4EBP1 (red) in the SVZ. L, Immunofluorescence staining for GFP (green) and P-S6-RP (red) in the SVZ of GFAP-GFP transgenic mice. Scale bars: (in $\boldsymbol{H}$ ) $\boldsymbol{C}-\boldsymbol{H}$, $25 \boldsymbol{\mu m}$; $\boldsymbol{K}, \boldsymbol{L}, 40 \mu \mathrm{m}$. Arrows indicate double-labelled cells.

(1) EGF-family ligands are major proliferative signals in the SVZ niche and (2) EGF can be used to generate neurosphere cultures of tripotential neural progenitors from the adult brain, we next used multiple in vitro paradigms to directly study the role of mTOR signaling during EGF-induced proliferative expansion of neural precursors.

First, serum-free suspension cultures of tripotential neural progenitors were generated with EGF and FGF2 for $7 \mathrm{~d}$ using the colonyforming neurosphere method (Reynolds and Weiss, 1992). Following overnight deprivation of serum and growth factors (EGF, FGF2, and insulin-containing B27 supplement) from dissociated and plated neurosphere cells, acute stimulation with EGF triggered a rapid increase in P-mTOR ${ }^{\mathrm{Ser} 2448}$, in the mTORC1 downstream targets P-S6-RP ${ }^{\text {Ser240/244 }}$ and P-Rictor ${ }^{\text {Thr1 } 135}$, and in the mTORC2 downstream target P-Akt ${ }^{\text {Ser473 }}$ (Fig. 4A), which were all detectable biochemically within $15 \mathrm{~min}$. To determine the consequences of blocking EGF-induced mTOR activation, we then used two mechanistically distinct pharmacological inhibitors of the mTOR signaling cascade, the mTORC1 inhibitor rapamycin and a more recently developed dual mTORC1/mTORC2 inhibitor, KU0063794 (GarciaMartinez et al., 2009; Malagu et al., 2009). Unlike the allosteric inhibitor rapamycin, KU0063794 is a highly selective ATPcompetitive mTOR inhibitor that blocks both mTORC1 and mTORC2 activity with an IC50 of $\sim 10 \mathrm{~nm}$. The specificity and ef- 

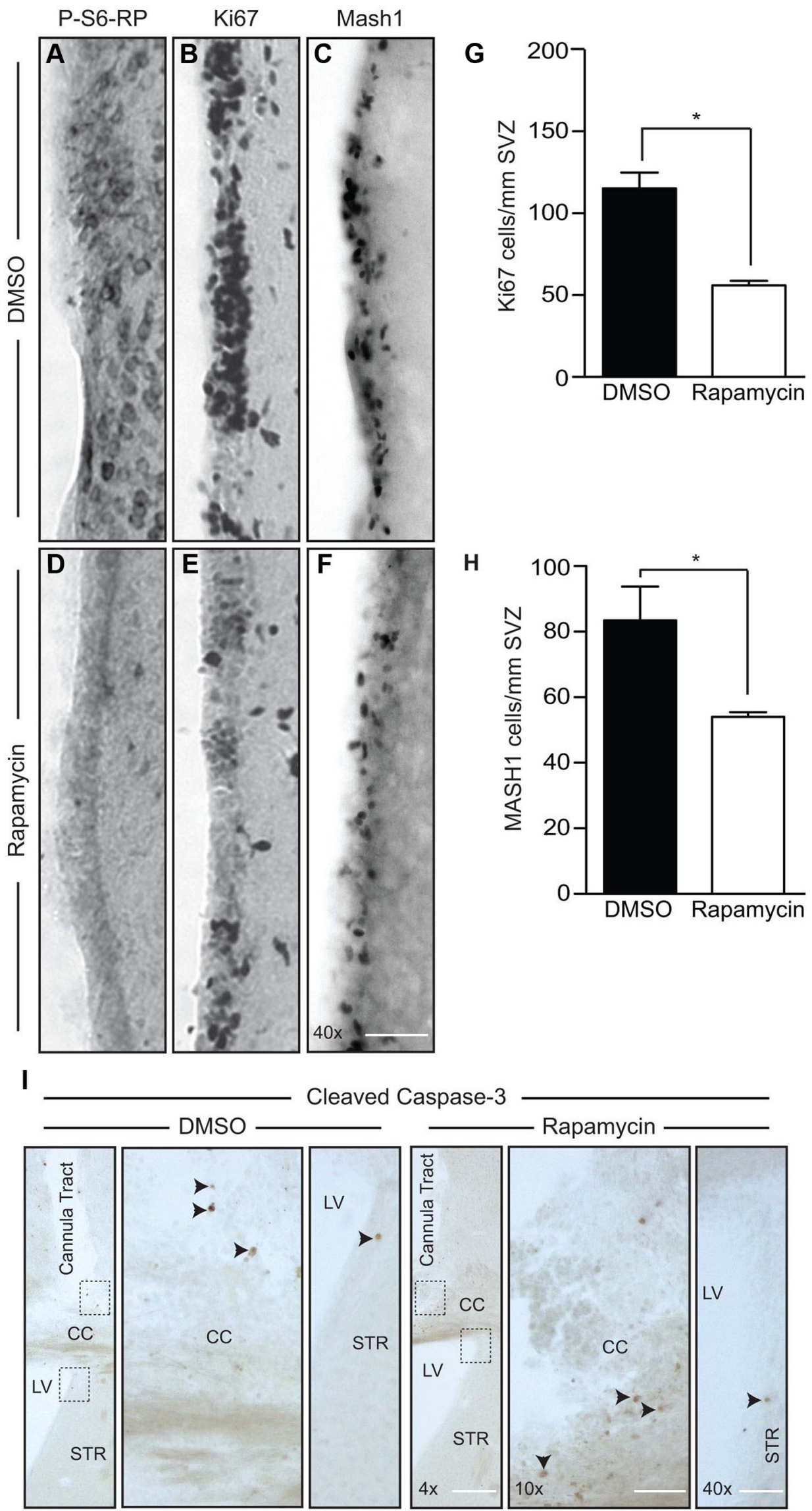

Figure 3. In vivo inhibition of mTORC1 with rapamycin decreases the proliferating TA progenitor pool in the SVZ. A-F, Immunostaining of SVZ sections from 2-month-old mice receiving $7 \mathrm{~d}$ ICV infusions of DMSO $(\boldsymbol{A}-\boldsymbol{C})$ or rapamycin $(\boldsymbol{D}-\boldsymbol{F}) . \boldsymbol{A}-\boldsymbol{C}, \boldsymbol{D}-\boldsymbol{F}$, Images of the striatal SVZ showing that immunoreactivity for P-S6-RP $(\boldsymbol{A}, \boldsymbol{D})$, Ki67 $(\boldsymbol{B}, \boldsymbol{E})$, and Mash1 $(\boldsymbol{C}, \boldsymbol{F})($ Figure legend continues.) 
A

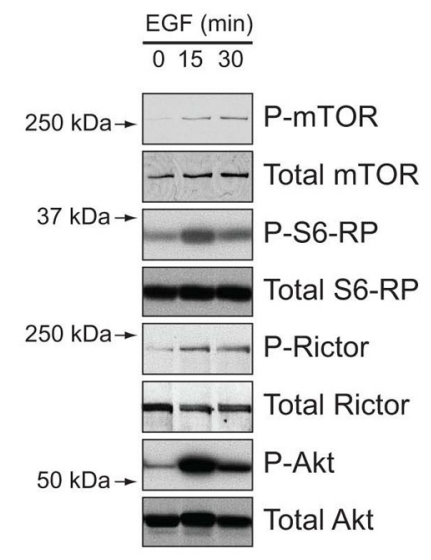

C

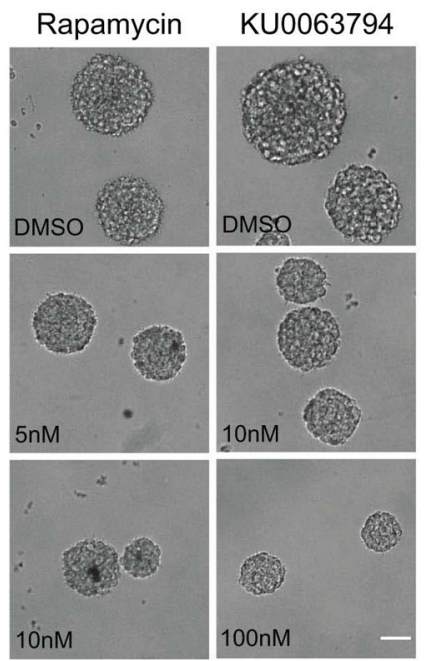

B
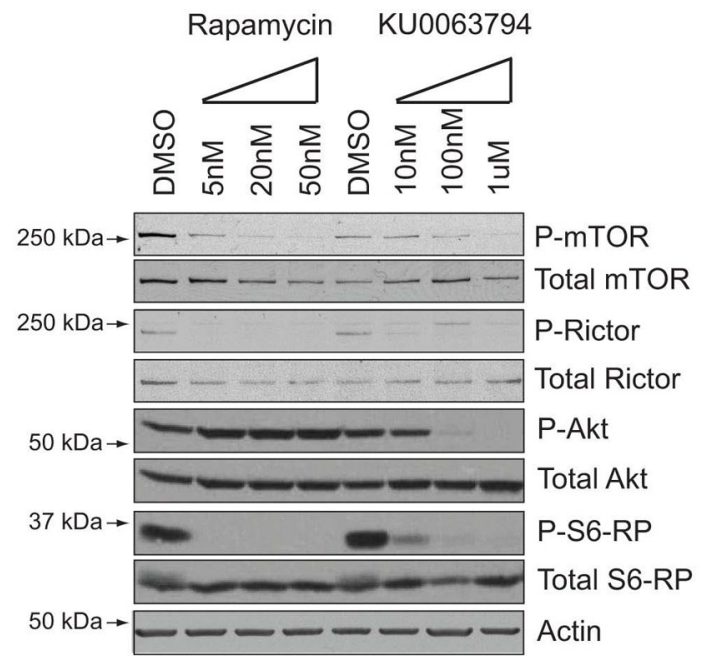

D
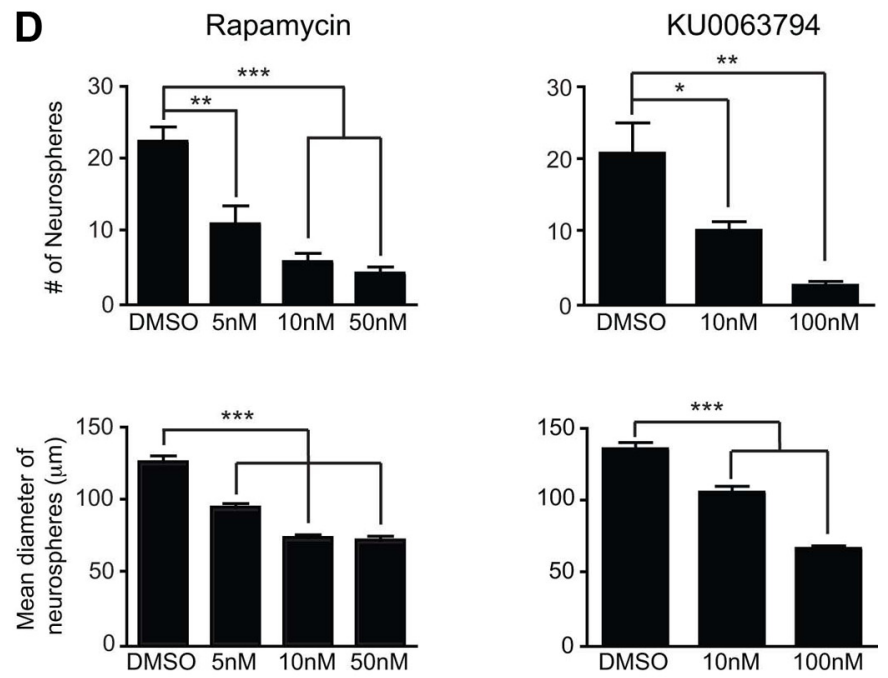
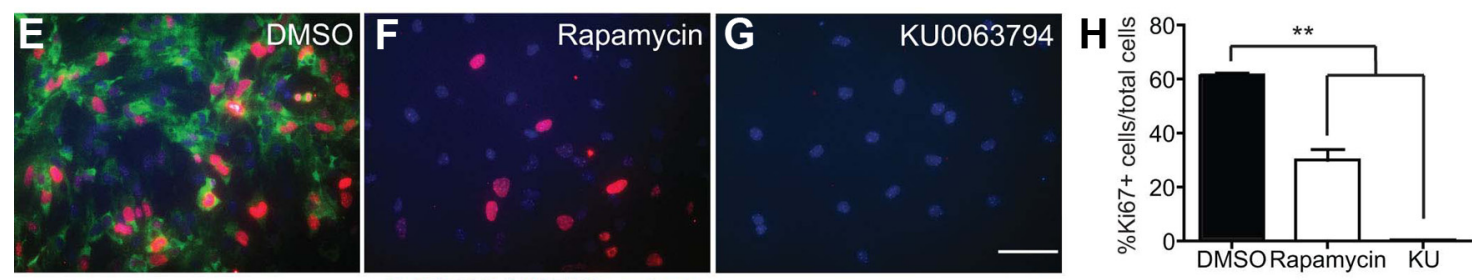

P-S6-RP/Ki67/Hoechst

Figure 4. mTOR signaling is an essential mediator of EGF-induced proliferation in neurosphere cultures of tripotential neural progenitors. $A$, Time course of mTOR, S6-RP, Rictor, and Akt phosphorylation in adult SVZ neurosphere cultures upon acute stimulation with $100 \mathrm{ng} / \mathrm{ml}$ EGF. Neurospheres were dissociated, plated overnight in medium containing EGF and $1 \%$ serum, and then deprived of EGF, serum, and insulin overnight before EGF stimulation. B, Effects of the mTORC1 inhibitor, rapamycin, or the mTORC1/2 inhibitor KU0063794 on activation of mTOR signaling pathways. Primary neurospheres were dissociated and plated in the presence of EGF and B27 for $2 \mathrm{~d}$, and then the inhibitors were added at the indicated doses for 30 min before cell lysis. $C, D$, Images of the effects of rapamycin and KU0063794 on growth of secondary neurospheres in the presence by EGF, FGF2, and B27 (C). Quantifications show that rapamycin and KU0063794 cause a dose-dependent decrease in neurosphere number (upper graphs) and size (lower graphs) (D). $\boldsymbol{E}-\boldsymbol{H}$, Effects of rapamycin and KU0063794 on EGF-induced proliferation of adherent monolayer cultures of SVZ-derived neural precursors. Immunofluorescence for P-S6-RP (green) and Ki67 (red) following $3 \mathrm{~d}$ of stimulation with EGF with and without inhibitors shows that both inhibitors efficiently block S6-RP phosphorylation, and this is associated with partial (rapamycin) or complete (KU0063794) inhibition of cell proliferation. Quantification of Ki67 is shown in $\boldsymbol{H}$. Graphs show the mean \pm SEM from $n=4-6$ independent cultures. ${ }^{*} p<0.05$; ${ }^{* *} p<0.01$; ${ }^{* * *} p<0.0001$. Scale bars: C, (in G) $\boldsymbol{E}-\mathbf{G}, 50 \mu \mathrm{m}$.

$\leftarrow$

(Figure legend continued.) are all reduced by rapamycin infusion. $\boldsymbol{G}, \boldsymbol{H}$, Quantification of Ki67+ proliferating cells $(\boldsymbol{G})$ and Mash1+ progenitors $(\boldsymbol{H})$. Graphs show the mean and SEM from $n=3$ mice per treatment. ${ }^{*} p<0.05$. I, Cleaved caspase-3 immunostaining of DMSO or rapamycin ICV infusions. In both cases, some cells immunoreactive for activated caspase-3 could be seen surrounding the cortical cannula tract, but such cells were only rarely detectable within the SVZ (arrowheads). LV, Lateral ventricle; STR, striatum; CC, corpus callosum. Scale bars: $4 \times$ and $10 \times$ images, $200 \mu \mathrm{m} ; 40 \times$ images, $50 \mu \mathrm{m}$. fective dosages of these inhibitors on neurospheres (both in the nanomolar range) were established in preliminary experiments, which demonstrated that both rapamycin and KU0063794 reduce $\mathrm{P}-\mathrm{mTOR}^{\text {Ser2448 }}$ and the mTORC1 downstream targets P-S6-

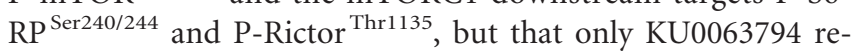
duces the level of the mTORC2 readout, P-Akt ${ }^{\text {Ser473 }}$ (Fig. $4 B$ ). Rapamycin-mediated inhibition of mTORC1 was also associated 
with consistent increases in $\mathrm{P}-\mathrm{Akt}^{\mathrm{Ser} 473}$; this is in agreement with mTORC1's reported cross-inhibition of mTORC2 activity (Julien et al., 2010) and, importantly, confirms that rapamycin treatment did not suppress mTORC2 activity as has been reported in some cell types under certain circumstances (Sarbassov et al., 2005; Zeng et al., 2007; Lamming et al., 2012). To assess the effects of these inhibitors on neurosphere growth, primary neurospheres were dissociated and grown into secondary neurospheres in EGF-containing medium supplemented with rapamycin, KU0063794 or DMSO (Fig. 4C,D). Quantification revealed that rapamycin and KU0063794 had similar effects on neurosphere growth: compared to DMSO, both inhibitors significantly reduced the number and size of neurosphere colonies grown in the presence of EGF in a dose-dependent fashion (Fig. 4D), indicating that mTORC1 activation is required for normal growth factor-induced expansion of tripotential neural progenitors.

Second, adherent cultures of proliferating tripotential neural progenitors were generated by dissociating primary neurospheres and plating the cells onto a poly-L-lysine-coated substrate in medium containing serum and EGF (Fig. 4E-H). Adherent cultures grown in the presence of EGF with or without mTOR inhibitors were immunostained for P-S6-RP ${ }^{\text {Ser240/244 }}$ after $3 \mathrm{~d}$. Both rapamycin and KU0063794 treatments completely abolished the high basal levels of mTORC1 activity (Fig. $4 E-G$ ). This was associated with significantly reduced numbers of Ki67+ proliferating cells, which fell to $51 \pm 13.1 \%$ in the presence of rapamycin and were entirely eliminated with KU0063794 (Fig. $4 E-H)$. Cell density in the presence of rapamycin and KU0073794 was lower than with DMSO treatment; this was mainly due to reduced proliferation rather than increased cell death, as mTOR inhibition with these inhibitors did not induce caspase- 3 activation by immunostaining (data not shown). In the case of KU0063794, occasional pyknotic nuclei were observed, which might indicate that prolonged mTORC1/2 inhibition eventually diminishes neural precursor survival; this would not be surprising given that the mTORC2 target, Akt, is also a well known mediator of survival-promoting growth factors (BarnabéHeider and Miller, 2003).

Together, these in vitro experiments establish mTOR signaling as a major mediator of EGF-induced proliferative expansion of adult SVZ-derived neural precursors.

mTOR inhibition in the absence of EGF induces a reversible, quiescence-like phenotype

Withdrawal of EGF from cultures of SVZ-derived neural precursors normally triggers a stereotyped differentiation of neurons $(\beta$ III-tubulin +$)$, astrocytes (GFAP +$)$, and oligodendrocytes (CNPase + ), as can be shown by Western blotting (Fig. 5A). Western blot time course analysis showed that this neuronal and glial differentiation is accompanied by a steady decline in overall P-S6-RP ${ }^{\text {Ser240/244 }}$ and P-Akt ${ }^{\text {Ser473 }}$ levels (Fig. 5A). Immunostaining confirmed that while both P-S6-RP $\mathrm{Ser}^{\text {S40/244 }}+$ and Ki67+ cells were maintained at high levels in the presence of EGF, P-S6-RP immunoreactivity was greatly reduced following $7 \mathrm{~d}$ of EGF withdrawal (Fig. 5B). Strong P-S6-RP immunoreactivity was retained only in a subpopulation of $\beta$ III-tubulin-expressing neurons and some CNPase-expressing oligodendrocytes; moreover, consistent with its expression pattern in the SVZ, P-S6-RP was virtually undetectable in GFAP-expressing astrocytes (Fig. 5B). Thus, mTORC1 activation is high in undifferentiated neural precursors, declines during EGF withdrawal-induced differentiation, and is then reexpressed in maturing neurons and oligodendrocytes.
To assess the consequences of mTOR inhibition on the pattern of NSC differentiation, cultures were differentiated for $7 \mathrm{~d}$ in the continuous presence of DMSO, rapamycin or KU0063794 (Fig. 5C,D). Inhibitor specificity was maintained after $7 \mathrm{~d}$, as rapamycin-treated cells showed reductions in mTORC1 targets P-S6-RP ${ }^{\text {Ser240/244 }}$ and P-Rictor ${ }^{\text {Thr1135, but not in the mTORC2 }}$ target P-Akt ${ }^{\text {Ser473, }}$, while KU0063794-treated cells showed a reduction in targets of both mTORC1 and mTORC2 (Fig. 5C). Similar to their effects in EGF-treated cultures, both rapamycin and KU0063794 treatments further reduced the low level of cell proliferation found in differentiating cultures, as shown by decreased expression of PCNA (Fig. 5C). Unexpectedly, however, rapamycin and KU0063794 treatments also attenuated differentiation into all three neural lineages (neuronal, oligodendrocytic, and astrocytic) as measured both by Western blotting (Fig. $5 C$ ) and immunostaining (Fig. 5D) for $\beta$ III-tubulin, GFAP, and $\mathrm{CN}$ Pase. Inhibitor-treated cells still retained a low level of Nestin expression (Fig. 5D). Despite the unusual lack of differentiation and proliferation, and concurrent low expression of Nestin, the inhibitor-treated cells remained healthy: baseline apoptosis in the cultures (as measured by cleaved caspase-3) was decreased (Fig. $5 C)$ rather than increased, pyknotic nuclei were not visible with Hoechst labeling (Fig. 5E), and the overall cellular morphology was normal (Fig. 5E). Thus, mTOR inhibition leads to a nonproliferating, nondifferentiating phenotype, which is reminiscent of aging-associated neural precursor quiescence.

These findings were independently supported by transiently transfecting neurosphere cells with plasmids encoding WT versus KD mTOR constructs. In control experiments, HEK293 cells transfected with mTOR(KD) showed detectable reductions in overall levels of P-S6-RP ${ }^{\text {Ser240/244 }}$ and P-4EBP1 $1^{\text {Thr37/46 }}$ when compared to $\mathrm{mTOR}(\mathrm{WT})$ transfection, confirming inhibition of mTOR signaling (Fig. $5 F$ ). We therefore transfected dissociated primary neurosphere cells, plated them for $6 \mathrm{~d}$ in differentiation conditions, and analyzed the fate of the transfected cells on a cell-by-cell basis by immunostaining (Fig. 5G,H). Quantification showed a $44 \%$ reduction in the proportion of transfected cells that differentiated into GFAP + astrocytes with $\mathrm{mTOR}(\mathrm{KD})$ [from $42.83 \pm 4.5 \%$ (WT) to $24.68 \pm 1.59 \%$ (KD); $n=4$ experiments]. In the case of neuronal differentiation, only $0.8 \pm 0.33 \%$ of mTOR(WT) cells became $\beta$ III-tubulin + neurons under these conditions, and this declined to $0.2 \pm 0.12 \%$ with mTOR(KD) but did not reach statistical significance $(p=0.19)$. An increase in Mash1 + cells was not detected, but weak Nestin immunoreactivity was maintained, suggesting that mTOR(KD)-transfected cells retained immature qualities.

To further test the idea that mTOR-inhibited cells retain undifferentiated properties, we assessed whether the inhibition of differentiation observed by rapamycin treatment was a reversible process. Specifically, we asked whether subsequent withdrawal of rapamycin from "quiescent" cultures would permit neurogenesis and gliogenesis to resume (Fig. 6). As previously, rapamycin treatment of differentiating NSC cultures for $5 \mathrm{~d}$ abolished P-S6-RP immunoreactivity and inhibited immunoreactivity for $\beta$ III-tubulin + neurons and GFAP + astrocytes (Fig. 6A). Following an additional 4-5 d of differentiation with rapamycin withdrawal, $\beta$ III-tubulin + neurons and GFAP + astrocytes reappeared in the quiescent cultures, as shown by immunostaining and counts of $\beta$ III-tubulin + cells (Fig. $6 A, B$ ). We confirmed and extended the analysis of this recovery of differentiation in parallel biochemical experiments: rapamycin withdrawal was associated with recovery of phosphorylation of the MTORC1 downstream targets P-S6-RP ${ }^{\text {Ser240/244 }}, \mathrm{P}-4 \mathrm{EBP} 1^{\text {Thr37/46, }}$, and P-Rictor ${ }^{\text {Thr1135, }}$ 
A



C

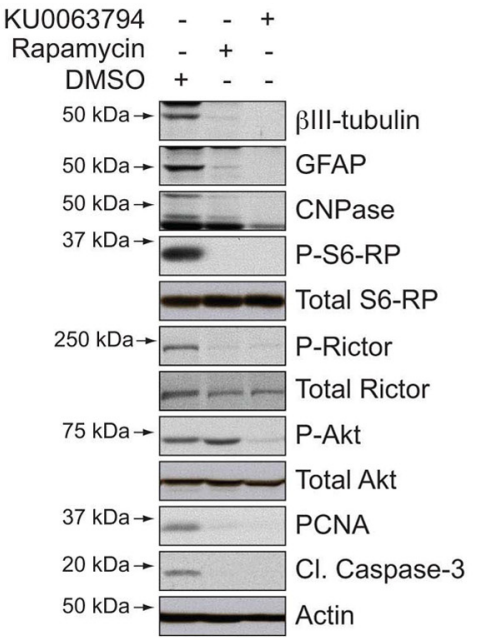

B

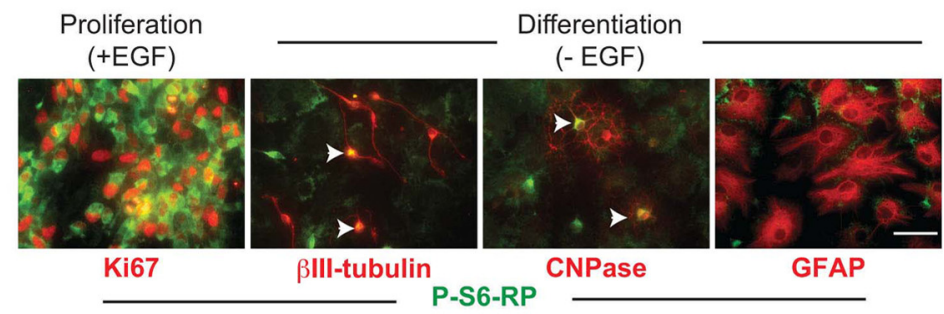

D

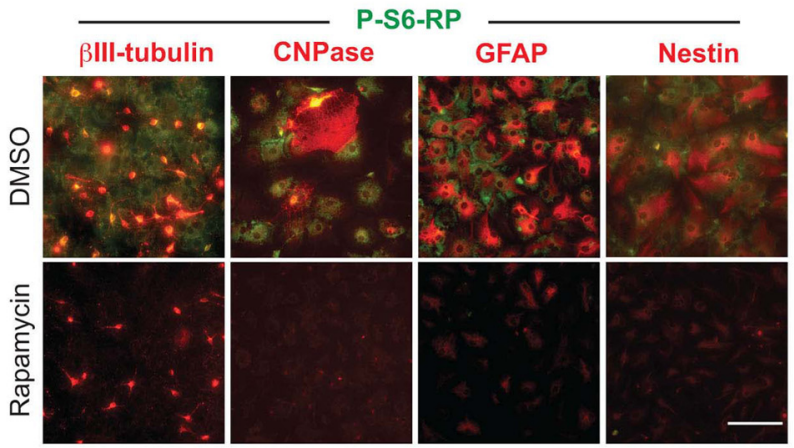

E



Brightfield

F

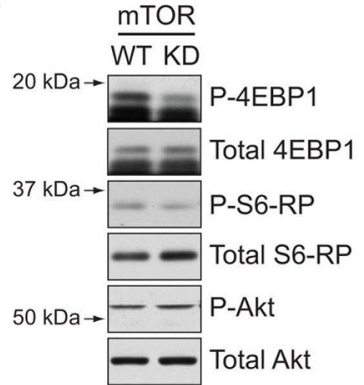

DMSO

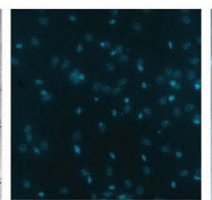

Hoechst



Merge

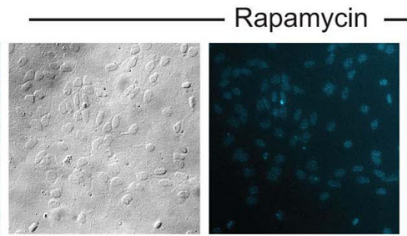

Brightfield

Hoechst



Merge

G

mTOR (WT)

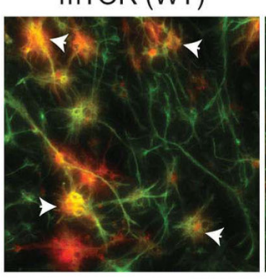

mTOR (KD)

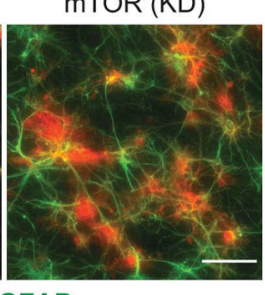

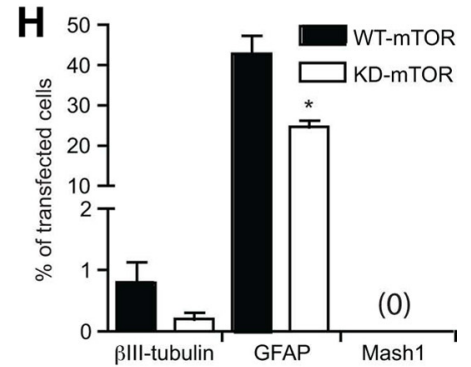

Figure 5. mTOR inhibition in the absence of EGF induces a quiescence-like phenotype in neurosphere cultures. $A, B$, Differentiation-induced changes in $m$ TOR signaling. Western blot analysis of biochemical changes in adult neurosphere cultures differentiating from 0 to $5 \mathrm{~d}$ in vitro (DIV) $(\boldsymbol{A})$, showing declining phosphorylation of S6-RP and Akt concomitant to generation of differentiated neurons ( $\beta$ III--tubulin) and astrocytes (GFAP). B, Immunocytochemistry showing the reduction in P-S6-RP immunoreactivity following EGF withdrawal-induced differentiation. Whereas high levels of P-S6-RP immunoreactivity are present during EGF-induced proliferation (left), strong P-S6-RP is maintained in only $\beta \| 11$-tubulin + neurons and CNPase + oligodendrocytes during differentiation (arrows), while GFAP + astrocytes are only weakly positive. C, D, mTOR inhibitors elicit a quiescence-like phenotype. C, Western blots showing biochemical changes in adult neurosphere cultures differentiated for 7 din the presence of DMSO, rapamycin $(20 \mathrm{nM})$, or KU0063794 (100 nm). Both mTOR inhibitors reduced expression of markers for proliferation (PCNA), differentiated neurons ( $\beta$ III-tubulin), astrocytes (GFAP), and oligodendrocytes (CNPase), and eliminated phosphorylation of the mTORC1 targets S6-RP and Rictor. Only KU0063794 also blocked mTORC2-associated phosphorylation at Akt ${ }^{\text {Ser473 }}$. D, Immunocytochemical changes in neurosphere cultures differentiated with DMSO versus rapamycin for $7 \mathrm{~d}$. Rapamycin treatment decreased expression of markers for differentiated neurons, oligodendrocytes, and astrocytes, as well as the expression of the neural precursor marker Nestin (representative results from 1 of 4 independent experiments). $\boldsymbol{E}$, Brightfield and fluorescent images of DMSO and rapamycin-treated cultures from $\boldsymbol{D}$ showing the absence of obvious morphological or nuclear signs of cell death, consistent with the inhibitor-induced reduction in cleaved caspase-3 in $C . F, G$, In vitro transfections with WT or KD forms of mTOR.F, Western blotting of lysates from HEK293 cells transfected for $2 \mathrm{~d}$ with mTOR(WT) or mTOR(KD) plasmids. Phosphorylation of 4-EBP1 and S6-RP are decreased by mTOR(KD). G, Immunocytochemistry for red fluorescent protein (RFP) and GFAP + astrocytes following transfection of dissociated neurospheres and $6 \mathrm{~d}$ of differentiation (arrows identify double-labelled cells). $\boldsymbol{H}$, Quantification following immunocytochemical analysis of transfected cells. Cells transfected with $\mathrm{mTOR}(\mathrm{KD})$ differentiate into fewer neurons and astrocytes and do not upregulate Mash1. Graph shows the mean and SEM from $n=4$ independent experiments (200 - 400 transfected cells analyzed per marker per experiment). ${ }^{*} p<0.05$. Scale bars: $B, G, 50 \mu \mathrm{m} ; \boldsymbol{D}, \boldsymbol{E}, 25 \mu \mathrm{m}$. 
A
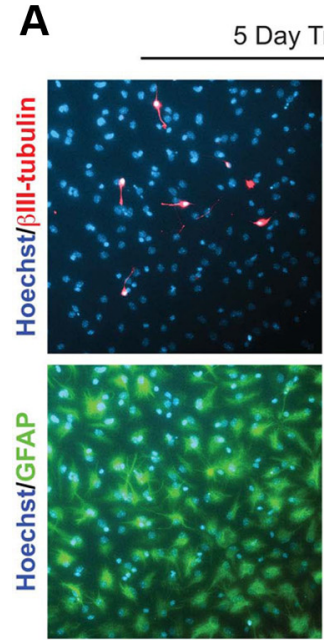

DMSO
Day Treatment
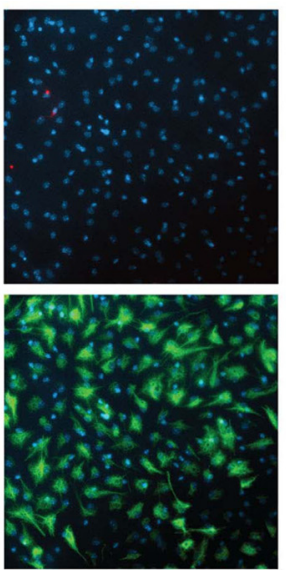

Rapamycin
5 Day Treatment + 4 Day withdrawal (DMSO)
9 Day Treatment

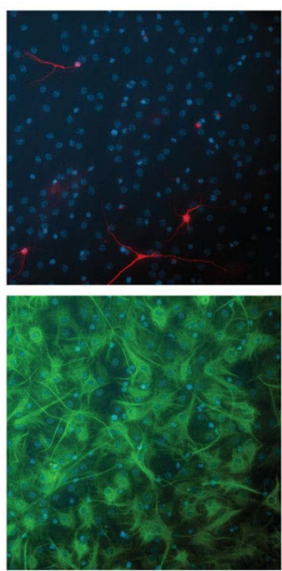

Rapamycin
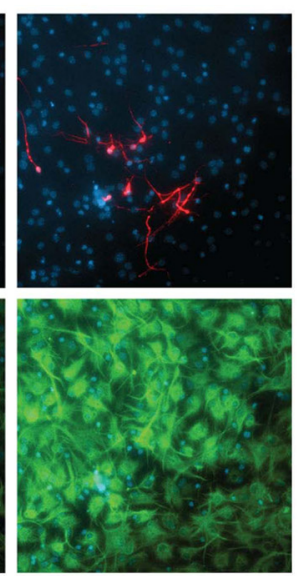

DMSO
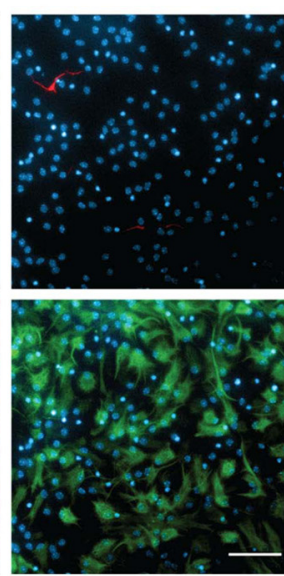

Rapamycin
B

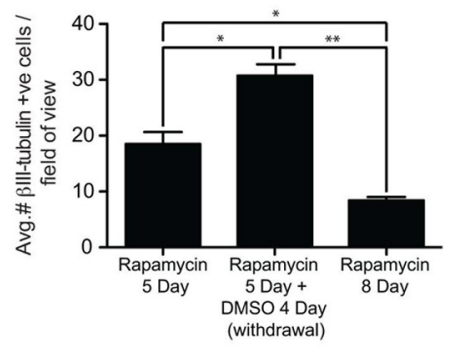

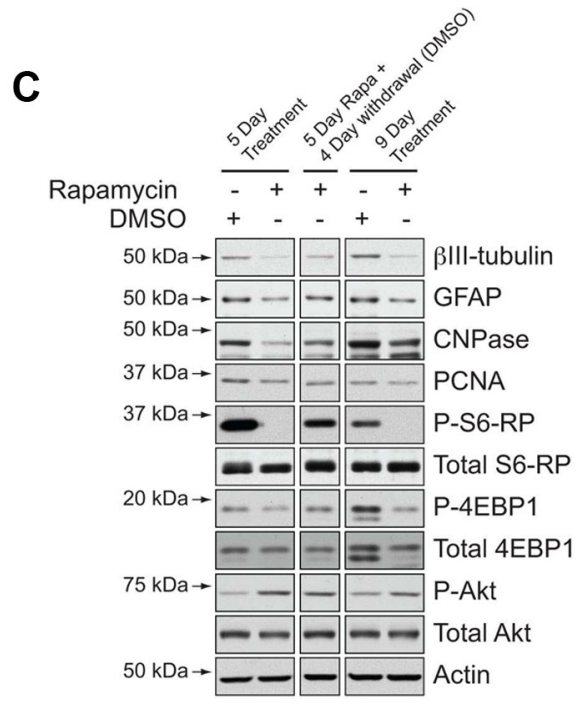

Figure 6. Rapamycin-induced quiescence of cultured neurosphere cells is reversible. Primary neurospheres were dissociated and plated in differentiation conditions for either (1) $5 \mathrm{~d}$ (supplemented with DMSO or rapamycin), (2) $9 \mathrm{~d}$ (5 d with rapamycin plus $4 \mathrm{~d}$ of rapamycin withdrawal), or (3) $9 \mathrm{~d}$ (DMSO or rapamycin for the entire period) as indicated. $A$, Immunocytochemistry for $\beta I l l$-tubulin + neurons and GFAP + astrocytes; note the reappearance of neurons and GFAP immunoreactivity following rapamycin withdrawal. $\boldsymbol{B}$, Quantification shows that $\beta$ III-tubulin + neuron number increases following rapamycin withdrawal. C, Western blotting of lysates from a parallel experiment; note the recovery in P-S6-RP and P-4EBP1 levels following rapamycin withdrawal and the associated increases in $\beta$ III-tubulin, GFAP, and CNPase levels. Five micrograms of protein were loaded per lane, and all bands for each probe were obtained from the same blot. ${ }^{*} p<0.05$; ${ }^{* *} p<$ 0.01. Scale bar, $25 \mu \mathrm{m}$.

and resulted in an increase in $\beta$ III-tubulin, GFAP and CNPase levels (Fig. 6C).

Together, these findings demonstrate that, in the absence of exogenous EGF proliferative signals, inhibiting mTOR activity leads neural precursors to adopt a reversible, quiescence-like phenotype.

mTOR signaling and cell proliferation decline in parallel in the quiescent SVZ of the aging brain

The phenotypic similarity between the effects of mTOR suppression in vitro and aging-associated SVZ quiescence in vivo prompted us to investigate the fate of the mTOR + TA progenitors in the aging brain. The NSC lineage in the adult SVZ becomes increasingly quiescent between early adulthood (2-3 months) and middle-age (10-12 months); over this period, the number of neurosphere-forming stem cells remains stable (Tropepe et al., 1997; Bouab et al., 2011), but the in vivo populations of TA progenitors and neuroblasts decline by $60-85 \%$ (Luo et al., 2006;
Bouab et al., 2011). We used immunofluorescence to identify $\mathrm{P}-\mathrm{S6} 6 \mathrm{RP}+$ cells and Ki67+ cells in the SVZ of 2-, 12-, and 18month-old mice (Fig. 7A). Quantifications revealed a coordinate decline in P-S6-RP+ cells, Ki67 + cells, and double-labeled cells $(\mathrm{P}-\mathrm{S6}-\mathrm{RP}+\mathrm{Ki67}+)$ (Fig. 7B). Consistent with our earlier results in 2-month-old mice, the vast majority of P-S6-RP+ cells remained Ki67+ at all ages, and these P-S6-RP+Ki67+ cells always constituted $18.8 \pm 5.9 \%$ of the entire Ki67 + cell population (Fig. $7 C)$. Thus, there is a strong correlation between decreasing mTOR activity and declining cell proliferation within the aging SVZ.

Quiescent neural precursors in the aging SVZ are reactivated by EGF-induced mTOR stimulation

We next asked whether EGF administration could be used to reactivate proliferation in the aging SVZ niche, and whether EGF-induced mTOR activation (Fig. 4) would be involved and/or necessary in this process. Osmotic pumps were used for 
A

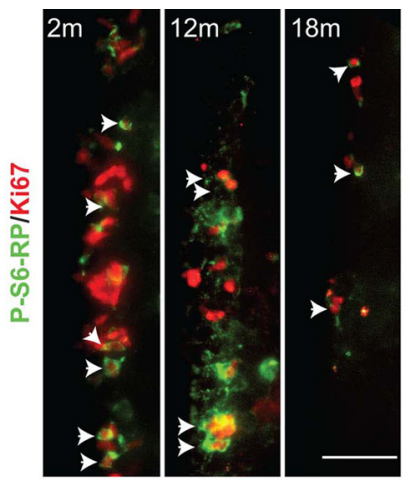

B
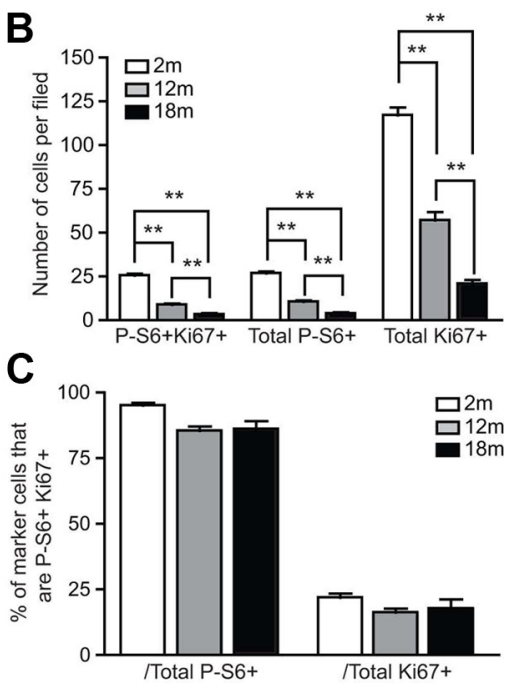

Figure 7. P-S6-RP immunoreactivity and cell proliferation decrease in parallel in the aging SVZ. A, Immunostaining for Ki67-positive proliferating cells and P-S6-RP-positive cells in the SVZ of 2-month-old (2m), 12-month-old (12m), and 18-month-old (18m) mice (arrows identify double-labelled cells). B, C, Quantifications of Ki67-positive and P-S6-RP-positive cells, expressed either as numbers of single or double-labeled cells per field (2 ventricles per mouse; $n=3$ mice per age; $\boldsymbol{B}$ ) or as percentage of the single-labeled populations that are double labeled ( $($ ). At all ages, the percentage of the P-S6-RP + proliferating cells remains stable at $\sim 16-22 \%$. Graphs show the mean and SEM. ${ }^{* *} p<0.01$. Scale bar, $25 \mu \mathrm{m}$.

$7 \mathrm{~d} \mathrm{ICV}$ infusions of DMSO, EGF, or EGF plus rapamycin into the lateral ventricles of 10-month-old mice (Fig. 8). Compared to 2-month-old mice, 10-month-old mice receiving DMSO infusions possessed fewer P-S6-RP+, Ki67+ and Mash1+ cells (compare Figs. $3 A-C, 8 A-C$ ). Aging neural precursors indeed remained responsive to EGF-induced mTOR activation, as EGF infusion stimulated the reappearance of P-S6-RP throughout the SVZ of 10-month-old mice (Fig. $8 D$ ). Remarkably, this was associated with a complete restoration of SVZ cell proliferation, as the numbers of both Ki67+ proliferating cells (Fig. $8 E$ ) and Mash1+ TA progenitors (Fig. $8 F$ ) were normalized to the levels found in 2-month-old mice (Fig. $8 \mathrm{~J}, \mathrm{~K}$ ). To assess the involvement of EGF-induced upregulation of mTOR signaling during this reactivation of the SVZ, we analyzed mice that received coinfusion of rapamycin with EGF. Importantly, rapamycin coinfusion completely eliminated the EGF-induced increases in P-S6-RP, Ki67+ cells and Mash1+ cells (Fig. 8G-K). Together, these in vivo experiments reveal that quiescent SVZ neural precursors in the aging brain can be reactivated by EGF in an mTORdependent manner, identifying mTOR signaling as a potential target for reversing aging-associated SVZ quiescence.

\section{Discussion}

The ability of neural stem cells to maintain a pool of proliferating TA progenitors is critical for efficiently controlling neural cell production in the adult brain. In this regard, our investigation of the mTOR signaling pathway allows us to draw three novel and important conclusions. First, mTORC1 signaling is specifically activated in the TA progenitor cells of the SVZ niche. This cell type specificity is unexpected given the wide array of cellular functions mTOR has been shown to regulate (Zoncu et al., 2011) and identifies the mTOR signaling pathway as a novel, stagespecific molecular target for modulating activity of the SVZ niche. Second, mTOR signaling is important for the proliferation of the TA progenitor pool in response to exogenous EGF or endogenous proliferative signals, acting as a critical mediator of proliferative expansion in the adult SVZ neurogenic niche. Third, our experiments demonstrate important links between downregulation of $\mathrm{mTOR}$ signaling and quiescence of the SVZ during aging. These findings reveal the mTOR signaling pathway is a key regulator of neurogenesis in the adult and aging brain.

\section{mTOR: a stage-specific signaling pathway in the forebrain} NSC lineage

The complexity of intercellular regulation within the SVZ is highlighted by a growing list of secreted and membrane-bound extrinsic factors within this niche, including (but not limited to) the EGF, Notch, Ephrin, Sonic Hedgehog (SHH), BMP, plateletderived growth factor, Wnt, and vascular endothelial growth factor systems (Ihrie and Alvarez-Buylla, 2011). For instance, BMP-induced Smad signaling can promote stem cell quiescence, but is also important for neurogenesis, depending on the cell type expression patterns of type I and type II BMP receptors (Lim et al., 2000; Colak et al., 2008; Mira et al., 2010). The Notch-Delta system regulates the activity of both astrocytic stem cells and ependymal niche cells (Carlén et al., 2009; Aguirre et al., 2010). Eph-Ephrin signaling influences multiple aspects of the SVZ niche, including the ability of ependymal niche cells to acquire stem cell properties (Conover et al., 2000; Nomura et al., 2010). These families activate diverse signaling events, generally across overlapping subpopulations of SVZ cell types, making it challenging to interpret, define, and ultimately manipulate cell type-specific signaling pathways to achieve specific biological outcomes.

In the present study, we found that mTOR-associated signaling pathways were specifically activated within the constitutively proliferating pool of TA progenitors in the SVZ niche. Less than $10 \%$ of SVZ cells exhibited P-S6-RP immunoreactivity, and the vast majority of these expressed Ki67 with Mash1 and/or Olig2, a marker profile characteristic of the TA progenitor population. P-S6-RP immunoreactivity was never observed in GFAPexpressing SVZ cells, including in GFAP + Ki67 + cells; this indicates that the mTORC1 branch of mTOR signaling is not activated within the quiescent or activated pools of neural stem cells, although it should be noted that MTOR may still have basal or mTORC2-mediated functions in these cells. Moreover, in the context of therapeutic approaches, it also should be recognized that prolonged activation of the TA progenitor population might conceivably lead to a secondary effect on the stem cell pool. Nevertheless, these findings identify mTOR signaling as a potential target pathway for specifically modulating the biologically crucial TA progenitor population of the SVZ niche. It will be of great interest to evaluate whether mTOR activity is also specifically enriched within the TA progenitor populations of other adult tissues as well. 

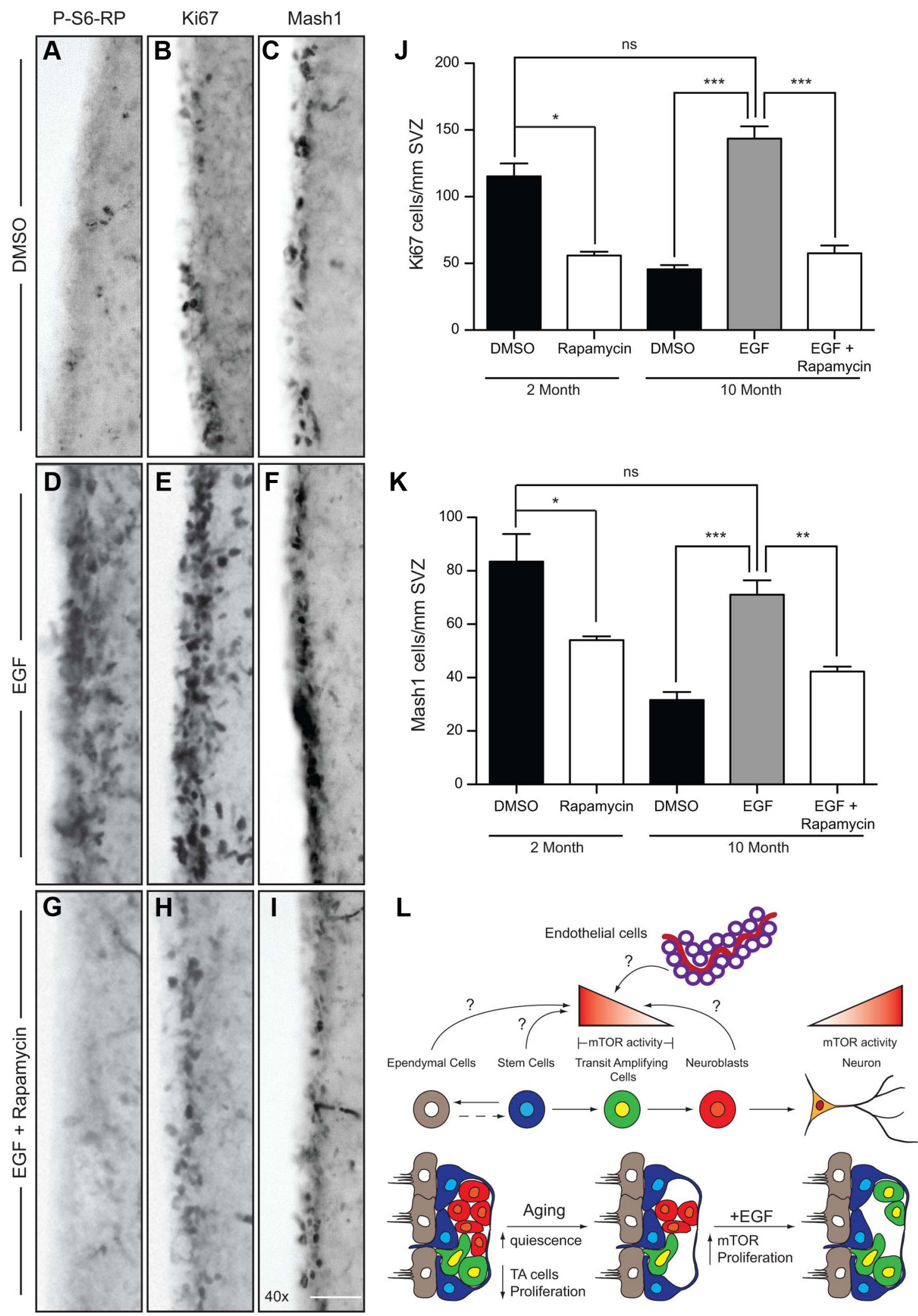

Figure 8. EGF infusion stimulates an mTOR-dependent reactivation of proliferation in the aging brain. $A-I$, Immunostaining of the SVZ on sections from 10 -month-old mice that had received ICV infusions of DMSO $(\boldsymbol{A}-\boldsymbol{C})$, EGF $(\boldsymbol{D}-\boldsymbol{F})$, or EGF plus rapamycin $(\boldsymbol{G}-\boldsymbol{I})$ for 7 d. Shown is immunoreactivity for P-S6-RP $(\boldsymbol{A}, \boldsymbol{D}, \boldsymbol{G})$, Ki67 + proliferating cells $(\boldsymbol{B}, \boldsymbol{E}, \boldsymbol{H})$, and Mash1+ progenitors $(\boldsymbol{C}, \boldsymbol{F}, \boldsymbol{I})$. Note that EGF treatment enhances the levels of all three markers in the aged brain, and these effects are blocked by rapamycin coinfusion. $\boldsymbol{J}, \boldsymbol{K}$, Quantification of Ki67+ proliferating cells $(\boldsymbol{J})$ or Mash1+ progenitors $(\boldsymbol{K})$. For reference, the 2 month results quantified in Figure 3 are included to show the impact of aging on the Ki67+ and Mash1+ populations. Note that Ki67+ and Mash1 + cells in 10-month-old mice recovered to the levels found in 2-month-old mice as a result of EGF infusion, and that this effect was entirely blocked by rapamycin. Graphs show the mean and SEM of $n=3$ mice per treatment group. L, mTOR activity is present within the TA population (defined as Ki67+Mash1+ or Ki67+0lig2+) and modulates their proliferation, differentiation, and quiescence. Brain aging is associated with a decrease in mTOR activity and reduction in the size of the proliferating TA progenitor pool, while the size of the stem (Figure legend continues.) 


\section{mTOR: a key player in the dynamic regulation of the TA progenitor pool in the adult SVZ}

Previous studies have implicated the mTOR signaling pathway in regulating the proliferation and/or self-renewal capacity of neural stem/progenitors in the rapidly developing embryonic and early postnatal brain (Sinor and Lillien, 2004; Sato et al., 2010; Magri et al., 2011; Raman et al., 2011). Our data indicate that mTOR signaling continues to play a role in neural precursors of the mature brain, where activation of mTOR signaling in TA progenitor cells is necessary for the maintenance and proliferation of the TA progenitor pool in vitro and in vivo. Interestingly, while only $\sim 20 \%$ of Ki67+ cells were found to be P-S6-RP+ at any given time in the SVZ, mTOR inhibition caused an $\sim 50 \%$ decline in the Ki67+ cell population; this may indicate that $\mathrm{P}-\mathrm{S6}$-RP activation is dependent on cell cycle stage or, alternatively, that the P-S6-RP+ cells represent a subpopulation of more primitive TA progenitor cells.

A complex issue that will require further studies is the precise reasons for the reduction in mTOR activity with aging (Fig. $8 \mathrm{~L}$ ). While we focused on EGF-R signaling in our experiments, niche factors such as $\mathrm{SHH}$, Wnts, and FGFs likewise exert proliferative effects within the SVZ, and potentially act through mTOR modulation as well. Besides the ligands themselves, age-related changes also may occur at the level of receptor expression, as the EGF-R is reportedly downregulated during aging (Enwere et al., 2004). Finally, there is an added layer of complexity arising from the previous demonstration that systemically derived circulating signals also contribute to aging-associated changes in neurogenesis (Villeda et al., 2011). On this complex backdrop, mTOR signaling potentially serves as a readout of proliferative stimuli and a target for intervention.

Clues to the regulation of mTOR activity in TA progenitors may be provided by the anatomical localization of TA progenitor cells within their niche. TA progenitor cells are found closely aligned along the SVZ plexus of blood vessels, directly contacting blood vessel endothelial cells at sites where the blood-brain barrier is absent (Shen et al., 2008; Tavazoie et al., 2008). This localization of TA progenitors means they are ideally positioned to be regulated by blood vessel endothelial cells (Rosa et al., 2010; Galan-Moya et al., 2011) or by blood nutrient status (Zoncu et al., 2011). Thus, mTOR signaling in TA progenitors represents a tantalizing potential node of signaling integration between cell surface growth factor receptors, such as EGF-R, and nutrient regulation of stem/progenitor activity.

\section{mTOR, aging, and reactivation of the quiescent SVZ niche} The present study identifies a new and fundamental role for mTOR signaling in the regulation of TA progenitor quiescence. mTOR inhibition yielded a quiescence-like phenotype in vitro, while EGF-induced upregulation of mTOR activity enabled the reactivation of the quiescent SVZ niche within the aging brain. EGF infusion had remarkable effects on the aged SVZ niche, restoring levels of $\mathrm{P}-\mathrm{S} 6-\mathrm{RP}+$ cells, proliferating cells, and Mash1+ TA progenitor cells to the levels found in the young

(Figure legend continued.) cell population remains stable. Growth factors such as EGF can reactivate proliferative expansion of the TA progenitor population in the aging SVZ, and stimulation of $m$ TOR activity is essential for this effect. The endogenous signals that stimulate mTOR activity in the young adult brain and that decrease in the aging brain are currently unknown, and might normally originate from the neural precursors themselves (i.e., stem cells, progenitors, or neuroblasts) or from supportive niche cells such as ependymal or blood vessel endothelial cells. ns, Not significant. ${ }^{*} p<0.05$; ${ }^{* *} p<0.01$; ${ }^{* * *} p<0.0001$. Scale bar: (in $\left.G\right) A-I, 50 \mu \mathrm{m}$. adult. Interestingly, previous studies have shown that EGFinduced proliferation, at least in the young adult SVZ, eventually leads to a major expansion of the oligodendrocyte lineage (Gonzalez-Perez et al., 2009; Gonzalez-Perez and Alvarez-Buylla, 2011). Furthermore, the mTOR signaling pathway has been implicated in both oligodendrocyte differentiation and later stages of myelination (Tyler et al., 2009; Zou et al., 2011; Guardiola-Diaz et al., 2012). Thus, whether mTOR signaling affects expansion of the TA progenitor population in a generalized or more lineage-specific fashion remains to be established.

Importantly, the involvement of mTOR signaling in EGFinduced reactivation of the quiescent SVZ leads to the hypothesis that aging-induced quiescence of the NSC lineage may be largely due to regulatory changes occurring at the level of the TA progenitors rather than the stem cell population. In line with this idea, the aging SVZ undergoes a reduction in TA progenitor cells but not astrocyte-like stem cells (Luo et al., 2006). Moreover, we have shown previously that equal numbers of cells having stem cell potential can be isolated from the SVZ between early and mid-adulthood, despite the fact that proliferation and the TA progenitor pool is reduced by $>50 \%$ (Bouab et al., 2011). Our findings suggest that specifically targeting the TA progenitor pool may be an effective approach for reversing quiescence in the SVZ; it will therefore be essential to evaluate how the regulatory mechanisms specifically controlling mTOR activity and TA progenitor proliferation are altered during the aging process.

Interestingly, it has been well established that mTOR is a powerful regulator of an organism's longevity across a variety of invertebrate and vertebrate model systems. In mice, significant lifespan extensions are produced by chronic mTOR suppression with rapamycin, by knock-out of the $\mathrm{mTORC1}$ effector S6 kinase, or by nutrient deprivation (Harrison et al., 2009; Selman et al., 2009; Kapahi et al., 2010; Kenyon, 2010; Zoncu et al., 2011). Given the central role of adult tissue stem cells in tissue maintenance and repair, the fact that $\mathrm{mTOR}$ inhibition induces a quiescence-like phenotype in neural precursors and promotes lifespan extension seems somewhat counterintuitive. This may be due to differences between ICV treatment with rapamycin and the systemic approaches used in lifespan studies, or might suggest that the longevity-promoting effects are primarily mediated through effects on differentiated cell types and/or suppression of the immune system. Alternatively, if SVZ stem cells have a finite lifetime or are capable of only a limited number of divisions as suggested previously in the hippocampus (Encinas et al., 2011), mTOR inhibition could conceivably contribute to long-term tissue maintenance by enabling neural precursors to persist further into old age. Such questions are of prime interest, considering the hopes for NSC-based regenerative therapies, and await further analysis.

\section{References}

Aguirre A, Rubio ME, Gallo V (2010) Notch and EGFR pathway interaction regulates neural stem cell number and self-renewal. Nature 467:323-327. CrossRef Medline

Arvidsson A, Collin T, Kirik D, Kokaia Z, Lindvall O (2002) Neuronal replacement from endogenous precursors in the adult brain after stroke. Nat Med 8:963-970. CrossRef Medline

Barnabé-Heider F, Miller FD (2003) Endogenously produced neurotrophins regulate survival and differentiation of cortical progenitors via distinct signaling pathways. J Neurosci 23:5149-5160. Medline

Bouab M, Paliouras GN, Aumont A, Forest-Bérard K, Fernandes KJ (2011) Aging of the subventricular zone neural stem cell niche: evidence for quiescence-associated changes between early and mid-adulthood. Neuroscience 173:135-149. CrossRef Medline

Carlén M, Meletis K, Göritz C, Darsalia V, Evergren E, Tanigaki K, Amendola 
M, Barnabé-Heider F, Yeung MS, Naldini L, Honjo T, Kokaia Z, Shupliakov O, Cassidy RM, Lindvall O, Frisén J (2009) Forebrain ependymal cells are Notch-dependent and generate neuroblasts and astrocytes after stroke. Nat Neurosci 12:259-267. CrossRef Medline

Chojnacki AK, Mak GK, Weiss S (2009) Identity crisis for adult periventricular neural stem cells: subventricular zone astrocytes, ependymal cells or both? Nat Rev Neurosci 10:153-163. CrossRef Medline

Colak D, Mori T, Brill MS, Pfeifer A, Falk S, Deng C, Monteiro R, Mummery C, Sommer L, Götz M (2008) Adult neurogenesis requires Smad4mediated bone morphogenic protein signaling in stem cells. J Neurosci 28:434-446. CrossRef Medline

Coles-Takabe BL, Brain I, Purpura KA, Karpowicz P, Zandstra PW, Morshead CM, van der Kooy D (2008) Don't look: growing clonal versus nonclonal neural stem cell colonies. Stem Cells 26:2938-2944. CrossRef Medline

Conover JC, Doetsch F, Garcia-Verdugo JM, Gale NW, Yancopoulos GD, Alvarez-Buylla A (2000) Disruption of Eph/ephrin signaling affects migration and proliferation in the adult subventricular zone. Nat Neurosci 3:1091-1097. CrossRef Medline

Doetsch F, García-Verdugo JM, Alvarez-Buylla A (1997) Cellular composition and three-dimensional organization of the subventricular germinal zone in the adult mammalian brain. J Neurosci 17:5046-5061. Medline

Doetsch F, García-Verdugo JM, Alvarez-Buylla A (1999) Regeneration of a germinal layer in the adult mammalian brain. Proc Natl Acad Sci U S A 96:11619-11624. CrossRef Medline

Doetsch F, Petreanu L, Caille I, Garcia-Verdugo JM, Alvarez-Buylla A (2002) EGF converts transit-amplifying neurogenic precursors in the adult brain into multipotent stem cells. Neuron 36:1021-1034. CrossRef Medline

Encinas JM, Michurina TV, Peunova N, Park JH, Tordo J, Peterson DA, Fishell G, Koulakov A, Enikolopov G (2011) Division-coupled astrocytic differentiation and age-related depletion of neural stem cells in the adult hippocampus. Cell Stem Cell 8:566-579. CrossRef Medline

Enwere E, Shingo T, Gregg C, Fujikawa H, Ohta S, Weiss S (2004) Aging results in reduced epidermal growth factor receptor signaling, diminished olfactory neurogenesis, and deficits in fine olfactory discrimination. J Neurosci 24:8354-8365. CrossRef Medline

Galan-Moya EM, Le Guelte A, Lima Fernandes E, Thirant C, Dwyer J, Bidere N, Couraud PO, Scott MG, Junier MP, Chneiweiss H, Gavard J (2011) Secreted factors from brain endothelial cells maintain glioblastoma stemlike cell expansion through the mTOR pathway. EMBO Rep 12:470-476. CrossRef Medline

García-Martínez JM, Moran J, Clarke RG, Gray A, Cosulich SC, Chresta CM, Alessi DR (2009) Ku-0063794 is a specific inhibitor of the mammalian target of rapamycin (mTOR). Biochem J 421:29-42. CrossRef Medline

Gonzalez-Perez O, Alvarez-Buylla A (2011) Oligodendrogenesis in the subventricular zone and the role of epidermal growth factor. Brain Res Rev 67:147-156. CrossRef Medline

Gonzalez-Perez O, Romero-Rodriguez R, Soriano-Navarro M, GarciaVerdugo JM, Alvarez-Buylla A (2009) Epidermal growth factor induces the progeny of subventricular zone type B cells to migrate and differentiate into oligodendrocytes. Stem Cells 27:2032-2043. CrossRef Medline

Guardiola-Diaz HM, Ishii A, Bansal R (2012) Erk1/2 MAPK and mTOR signaling sequentially regulates progression through distinct stages of oligodendrocyte differentiation. Glia 60:476-486. CrossRef Medline

Harrison DE, Strong R, Sharp ZD, Nelson JF, Astle CM, Flurkey K, Nadon NL, Wilkinson JE, Frenkel K, Carter CS, Pahor M, Javors MA, Fernandez E, Miller RA (2009) Rapamycin fed late in life extends lifespan in genetically heterogeneous mice. Nature 460:392-395. CrossRef Medline

Ihrie RA, Alvarez-Buylla A (2011) Lake-front property: a unique germinal niche by the lateral ventricles of the adult brain. Neuron 70:674-686. CrossRef Medline

Julien LA, Carriere A, Moreau J, Roux PP (2010) mTORC1-activated S6K1 phosphorylates Rictor on threonine 1135 and regulates mTORC2 signaling. Mol Cell Biol 30:908-921. CrossRef Medline

Kapahi P, Chen D, Rogers AN, Katewa SD, Li PW, Thomas EL, Kockel L (2010) With TOR, less is more: a key role for the conserved nutrientsensing TOR pathway in aging. Cell Metab 11:453-465. CrossRef Medline

Kenyon CJ (2010) The genetics of ageing. Nature 464:504-512. CrossRef Medline

Knoth R, Singec I, Ditter M, Pantazis G, Capetian P, Meyer RP, Horvat V, Volk B, Kempermann G (2010) Murine features of neurogenesis in the human hippocampus across the lifespan from 0 to 100 years. PLoS One 5:e8809. CrossRef Medline

Kolb B, Morshead C, Gonzalez C, Kim M, Gregg C, Shingo T, Weiss S (2007) Growth factor-stimulated generation of new cortical tissue and functional recovery after stroke damage to the motor cortex of rats. J Cereb Blood Flow Metab 27:983-997. Medline

Lamming DW, Ye L, Katajisto P, Goncalves MD, Saitoh M, Stevens DM, Davis JG, Salmon AB, Richardson A, Ahima RS, Guertin DA, Sabatini DM, Baur JA (2012) Rapamycin-induced insulin resistance is mediated by mTORC2 loss and uncoupled from longevity. Science 335:1638-1643. CrossRef Medline

Laplante M, Sabatini DM (2012) mTOR signaling in growth control and disease. Cell 149:274-293. CrossRef Medline

Li L, Clevers H (2010) Coexistence of quiescent and active adult stem cells in mammals. Science 327:542-545. CrossRef Medline

Lim DA, Tramontin AD, Trevejo JM, Herrera DG, García-Verdugo JM, Alvarez-Buylla A (2000) Noggin antagonizes BMP signaling to create a niche for adult neurogenesis. Neuron 28:713-726. CrossRef Medline

Luo J, Daniels SB, Lennington JB, Notti RQ, Conover JC (2006) The aging neurogenic subventricular zone. Aging Cell 5:139-152. CrossRef Medline

Magri L, Cambiaghi M, Cominelli M, Alfaro-Cervello C, Cursi M, Pala M, Bulfone A, García-Verdugo JM, Leocani L, Minicucci F, Poliani PL, Galli R (2011) Sustained activation of mTOR pathway in embryonic neural stem cells leads to development of tuberous sclerosis complex-associated lesions. Cell Stem Cell 9:447-462. CrossRef Medline

Malagu K, Duggan H, Menear K, Hummersone M, Gomez S, Bailey C, Edwards P, Drzewiecki J, Leroux F, Quesada MJ, Hermann G, Maine S, Molyneaux CA, Le Gall A, Pullen J, Hickson I, Smith L, Maguire S, Martin $\mathrm{N}$, Smith G, et al. (2009) The discovery and optimisation of pyrido[2,3d]pyrimidine-2,4-diamines as potent and selective inhibitors of mTOR kinase. Bioorg Med Chem Lett 19:5950-5953. CrossRef Medline

Maslov AY, Barone TA, Plunkett RJ, Pruitt SC (2004) Neural stem cell detection, characterization, and age-related changes in the subventricular zone of mice. J Neurosci 24:1726-1733. CrossRef Medline

Mira H, Andreu Z, Suh H, Lie DC, Jessberger S, Consiglio A, San Emeterio J, Hortigüela R, Marqués-Torrejón MA, Nakashima K, Colak D, Götz M, Fariñas I, Gage FH (2010) Signaling through BMPR-IA regulates quiescence and long-term activity of neural stem cells in the adult hippocampus. Cell Stem Cell 7:78-89. CrossRef Medline

Molofsky AV, Slutsky SG, Joseph NM, He S, Pardal R, Krishnamurthy J, Sharpless NE, Morrison SJ (2006) Increasing pl6INK4a expression decreases forebrain progenitors and neurogenesis during ageing. Nature 443:448-452. CrossRef Medline

Morshead CM, Reynolds BA, Craig CG, McBurney MW, Staines WA, Morassutti D, Weiss S, van der Kooy D (1994) Neural stem cells in the adult mammalian forebrain: a relatively quiescent subpopulation of subependymal cells. Neuron 13:1071-1082. CrossRef Medline

Nakada D, Levi BP, Morrison SJ (2011) Integrating physiological regulation with stem cell and tissue homeostasis. Neuron 70:703-718. CrossRef Medline

Nomura T, Göritz C, Catchpole T, Henkemeyer M, Frisen J (2010) EphB signaling controls lineage plasticity of adult neural stem cell niche cells. Cell Stem Cell 7:730-743. CrossRef Medline

Palma V, Lim DA, Dahmane N, Sánchez P, Brionne TC, Herzberg CD, Gitton Y, Carleton A, Alvarez-Buylla A, Ruiz i Altaba A (2005) Sonic hedgehog controls stem cell behavior in the postnatal and adult brain. Development 132:335-344. CrossRef Medline

Pastrana E, Cheng LC, Doetsch F (2009) Simultaneous prospective purification of adult subventricular zone neural stem cells and their progeny. Proc Natl Acad Sci U S A 106:6387-6392. Medline

Raman L, Kong X, Gilley JA, Kernie SG (2011) Chronic hypoxia impairs murine hippocampal development and depletes the postnatal progenitor pool by attenuating mammalian target of rapamycin signaling. Pediatr Res 70:159-165. CrossRef Medline

Reynolds BA, Weiss S (1992) Generation of neurons and astrocytes from isolated cells of the adult mammalian central nervous system. Science 255:1707-1710. CrossRef Medline

Rosa AI, Goncalves J, Cortes L, Bernardino L, Malva JO, Agasse F (2010) The angiogenic factor angiopoietin-1 is a proneurogenic peptide on subventricular zone stem/progenitor cells. J Neurosci 30:4573-4584. CrossRef Medline

Sarbassov DD, Guertin DA, Ali SM, Sabatini DM (2005) Phosphorylation 
and regulation of Akt/PKB by the rictor-mTOR complex. Science 307: 1098-1101. CrossRef Medline

Sato A, Sunayama J, Matsuda K, Tachibana K, Sakurada K, Tomiyama A, Kayama T, Kitanaka C (2010) Regulation of neural stem/progenitor cell maintenance by PI3K and mTOR. Neurosci Lett 470:115-120. CrossRef Medline

Selman C, Tullet JM, Wieser D, Irvine E, Lingard SJ, Choudhury AI, Claret M, Al-Qassab H, Carmignac D, Ramadani F, Woods A, Robinson IC, Schuster E, Batterham RL, Kozma SC, Thomas G, Carling D, Okkenhaug K, Thornton JM, Partridge L, et al. (2009) Ribosomal protein S6 kinase 1 signaling regulates mammalian life span. Science 326:140-144. CrossRef Medline

Shen Q, Wang Y, Kokovay E, Lin G, Chuang SM, Goderie SK, Roysam B, Temple S (2008) Adult SVZ stem cells lie in a vascular niche: a quantitative analysis of niche cell-cell interactions. Cell Stem Cell 3:289-300. CrossRef Medline

Sinor AD, Lillien L (2004) Akt-1 expression level regulates CNS precursors. J Neurosci 24:8531-8541. CrossRef Medline

Tavazoie M, Van der Veken L, Silva-Vargas V, Louissaint M, Colonna L, Zaidi B, Garcia-Verdugo JM, Doetsch F (2008) A specialized vascular niche for adult neural stem cells. Cell Stem Cell 3:279-288. CrossRef Medline

Thored P, Wood J, Arvidsson A, Cammenga J, Kokaia Z, Lindvall O (2007) Long-term neuroblast migration along blood vessels in an area with transient angiogenesis and increased vascularization after stroke. Stroke 38: 3032-3039. CrossRef Medline
Tropepe V, Craig CG, Morshead CM, van der Kooy D (1997) Transforming growth factor-alpha null and senescent mice show decreased neural progenitor cell proliferation in the forebrain subependyma. J Neurosci 17: 7850-7859. Medline

Tyler WA, Gangoli N, Gokina P, Kim HA, Covey M, Levison SW, Wood TL (2009) Activation of the mammalian target of rapamycin (mTOR) is essential for oligodendrocyte differentiation. J Neurosci 29:6367-6378. CrossRef Medline

Villeda SA, Luo J, Mosher KI, Zou B, Britschgi M, Bieri G, Stan TM, Fainberg N, Ding Z, Eggel A, Lucin KM, Czirr E, Park JS, Couillard-Després S, Aigner L, Li G, Peskind ER, Kaye JA, Quinn JF, Galasko DR, et al. (2011) The ageing systemic milieu negatively regulates neurogenesis and cognitive function. Nature 477:90-94. CrossRef Medline

Zeng Z, Sarbassov dos D, Samudio IJ, Yee KW, Munsell MF, Ellen Jackson C, Giles FJ, Sabatini DM, Andreeff M, Konopleva M (2007) Rapamycin derivatives reduce mTORC2 signaling and inhibit AKT activation in AML. Blood 109:3509-3512. CrossRef Medline

Zoncu R, Efeyan A, Sabatini DM (2011) mTOR: from growth signal integration to cancer, diabetes and ageing. Nat Rev Mol Cell Biol 12:21-35. CrossRef Medline

Zou J, Zhou L, Du XX, Ji Y, Xu J, Tian J, Jiang W, Zou Y, Yu S, Gan L, Luo M, Yang Q, Cui Y, Yang W, Xia X, Chen M, Zhao X, Shen Y, Chen PY, Worley $\mathrm{PF}$, Xiao B (2011) Rheb1 is required for mTORC1 and myelination in postnatal brain development. Dev Cell 20:97-108. CrossRef Medline 